\title{
52. PHENOCRYST AND GROUNDMASS PHASE COMPOSITIONS OF BASALTIC AND ANDESITIC SILLS AND FLOWS FROM THE JAPAN SEA RECOVERED DURING LEGS 127 AND $128^{1}$
}

\author{
P. Thy ${ }^{2}$
}

\begin{abstract}
Suites of basalts drilled during Legs 127 and 128 can be distinguished by their mineral assemblages and compositions of phenocrysts and groundmass phases. An upper suite of plagioclase phyric basaltic sills with a groundmass composed of plagioclase, augite, and magnetite was recovered from Site 794. The upper, evolved part of this suite is highly plagioclase phyric, including calcic plagioclases $\left(\sim \mathrm{An}_{90}\right)$. The most primitive, lower part of this upper suite, in addition, contains olivine, but lacks calcic plagioclase. A lower suite at Site 794 is plagioclase and olivine phyric to aphyric basaltic sills and flows with a groundmass of plagioclase, augite, olivine ( $\left.\sim \mathrm{FO}_{75-83}\right)$, and magnetite. At Site 795 , plagioclase and augite phyric basalts and andesites were recovered. The relatively low $\mathrm{Ti}$ and $\mathrm{Cr}$ contents of augite of these basalts suggest typical arc tholeitic parental magmas. Two suites of basalt were recovered from Site 797, an upper suite of plagioclase and olivine phyric to aphyric olivine basalts, and a lower suite of evolved plagioclase phyric basaltic sills. The most evolved sills at both sites lack olivine as phenocryst and groundmass phases, while this phase is present in the relatively primitive sills. The olivine-bearing suites contain plagioclase with relatively low potassium content and augite with relatively high sodium content. An exception is the olivine-bearing sills of the upper suite at Site 794 that contains plagioclase with relatively high potassium content similar to the associated olivine-free sills. The olivine-free suites contain plagioclase with high potassium content and augite with low sodium content and have the most evolved compositions of any of the Japan Sea rocks.
\end{abstract}

\section{INTRODUCTION}

Despite extensive studies in the Japan Sea for more than five decades, only little is known on the nature of the basement rocks underlying a thick sediment cover (Tamaki, 1988). The drilling on Leg 127 of the Ocean Drilling Project for the first time recovered extensive sections of basaltic basement at three sites in the Yamato (Sites 794 and 797) and Japan (Site 795) Basins of the Japan Sea. An upper suite of plagioclase phyric to aphyric doleritic sills and flows and a lower suite of plagioclase and olivine phyric basaltic sills and flows were recovered from Site 794 (Tamaki, Pisciotto, Allan, et al., 1990). Additional members of this lower suite were recovered by subsequent drilling on Leg 128, and were composed of plagioclase and olivine phyric to aphyric basaltic to doleritic sills (Ingle, Suyehiro, von Breymann, et al., 1990). At Site 795, sparsely plagioclase and clinopyroxene phyric massive to brecciated basaltic and andesitic flows were recovered. At Site 797, an upper suite of primitive plagioclase and olivine phyric to aphyric basaltic to doleritic sills and a lower suite of evolved, aphyric sills were recovered.

The majority of the rocks from all sites is highly altered (Allan and Gorton, this volume). In particular, the mafic phenocryst are frequently replaced by secondary mineral aggregates. However, phenocrysts and groundmass phases are partially preserved typically in the centers of thick sills. In this study, the mineral composition of relict phenocryst and groundmass phases have been characterized. The study augments the groupings based on the whole rock compositions (Allan and Gorton, this volume; Cousens and Allan, this volume).

\section{PETROGRAPHY}

\section{Site 794}

The upper suite is composed of at least five massive and moderately to highly vesicular sills, about $85 \mathrm{~m}$ thick and defined from Section 127-794B-27R-1 to Section 127-794C-13R-1 (Units 1-5;

\footnotetext{
${ }^{1}$ Tamaki, K., Suyehiro, K., Allan, J., McWilliams, M., et al., 1992. Proc. ODP, Sci. Results, 127/128, Pt. 2: College Station, TX (Ocean Drilling Program)

${ }^{2}$ Department of Geology, University of Botswana, Private Bag 0022, Gaborone, Botswana.
}

Tamaki, Pisciotto, Allan, et al., 1990). The margins are defined by a reduction in grain-size and a change from aphyric dolerite to porphyritic basalt. The central parts of the sills are composed of fine- to medium-grained dolerite, dominated by plagioclase laths in an intergranular to intersertal texture, relict subophitic to ophitic clinopyroxene, and small amounts of magnetite. Ólivine was not analyzed from any of the rocks examined. However, Tamaki, Pisciotto, Allan, et al. (1990) noted Cr-spinel in pseudomorphed olivine in the lower part of the suite (Unit 5), and Ingle, Suyehiro, von Breymann, et al. (1990) described pseudomorphed olivine phenocrysts in the same rock suite. It is therefore likely that olivine is an early crystallizing phase in the lower part of the upper suite at Site 794.

The uppermost part of this suite is composed of at least two massive sills, of about $35 \mathrm{~m}$ of total thickness, and defined from Section 127-794B-27R-1 to Section 127-794C-6R-1 (Units 1-2). The marginal parts of the sills are highly plagioclase phyric basalts with a microlitic groundmass. The interior of the sills is composed of coarsely porphyritic and seriate dolerite with a subophitic to granular groundmass dominated by laths of plagioclase with subordinate clinopyroxene and a small amount of magnetite. The dominant plagioclase phenocryst phase is zoned, euhedral to subhedral, and frequently glomeroporphyritic. Phenocrysts constitute $5 \%-15 \%$ of the rocks and their size may reach $5 \mathrm{~mm}$ in diameter. Olivine is absent in these rocks.

A lower suite at Site 794 is composed of at least four massive and fine-grained flows and sills with a total of $61 \mathrm{~m}$ defined from Section 127-794C-13R-2 to Section 128-794D-20R-1 (Units 6-9; Tamaki, Pisciotto, Allan, et al., 1990; Ingle, Suyehiro, von Breymann, et al., 1990). The correlation between Holes 794C and 794D has been based on a thin layer of sediments between Unit 5 and Unit 6 as defined during Leg 128 (Ingle, Suyehiro, von Breymann, et al., 1990). There is a systematic increase in the amount of vesicles toward the top parts of the flows/sills. Chilled margins are moderately plagioclase and olivine phyric basalts and contain reddish brown $\mathrm{Cr}$-spinel in a formerly glassy to spherulitic groundmass and in olivine pseudomorphs. More central parts are olivine and plagioclase microphyric with olivine, clinopyroxene, and plagioclase in an intersertal to intergranular groundmass (Pl. 1, 1-3). Subophitic clinopyroxene appears in central parts of the units. Only the uppermost part of this suite was drilled during Leg 127 (Hole 794C; Tamaki, Pisciotto, Allan, et al., 
1990); the extension at Site 794 on Leg 128 (Hole 794D; Ingle, Suyehiro, von Breymann, et al., 1990), however, penetrated deeper into this suite. The data, on which this paper is based, are for the upper suite from Hole 794C and for the lower suite from Hole 794D.

\section{Site 795}

An upper suite comprises a brecciated, $20 \mathrm{~m}$ thick, flow(s) defined from Section 127-797B-34R-1 to Section 127-795B-36R-1 (Unit 1; Tamaki, Pisciotto, Allan, et al., 1990). Compositionally, the flow is andesitic and moderately plagioclase and pyroxene phyric and vesicular. Phenocrysts are plagioclase, clinopyroxene, and magnetite (Pl. 1, 4). Plagioclase and clinopyroxene often occur in glomerophyric clusters. The groundmass is texturally microcrystalline and intersertal.

A lower suite is about $58 \mathrm{~m}$ thick, massive and moderately vesicular, basaltic flow(s) defined from Section 127-795B-36R-1 to Section 127-795B-41R-2 (Unit 3). The rock is sparsely pyroxene and plagioclase phyric with subhedral clinopyroxene and euhedral plagioclase phenocrysts in a microcrystalline, intersertal matrix.

\section{Site 797}

An upper suite of sills is composed of $126 \mathrm{~m}$ of sparsely vesicular basalt defined from Section 127-797C-8R-2 to Section 127-797C-25R-1 (Units 1-9; Tamaki, Pisciotto, Allan, et al., 1990). The basalts vary from sparsely plagioclase and olivine phyric to aphyric. $\mathrm{Cr}$-spinel is occasionally present as inclusions in olivine or in the groundmass. The groundmass is composed of plagioclase, olivine, clinopyroxene, and magnetite in an intersertal to intergranular and subophitic texture (PI. 1, 5). The late crystallizing clinopyroxenes often appear as radiating skeletal grains on plagioclase (Pl. 1,6). The chilled marginal parts are cryptocrystalline and spherulitic, but are completely replaced by secondary minerals.

A lower suite is composed of $93 \mathrm{~m}$ of massive, sparsely vesicular, basaltic sills defined from Section 127-797C-26R-1 to Section 127797C-45R-4 (Units 10-21). The basalts are mostly aphyric, but small amounts of plagioclase phenocrysts occur. The groundmass consists of plagioclase, clinopyroxene, and magnetite and is dominantly microcrystalline and intergranular to intersertal. Spherulitic and subophitic textures are characteristic of the chilled margins and interior parts, respectively. Although the sills are sparsely vesicular, chilled margins may be highly vesicular.

\section{MINERAL COMPOSITIONS}

Representative samples containing various amounts of relict groundmass and phenocryst phases from the major suites of flows and sills were selected for analysis with the electron microprobe (Appendix). All apparently unaltered phases, texturally from phenocrysts to groundmass phases, were analyzed. The analytical techniques included a focused beam, an acceleration voltage of $15 \mathrm{kV}$, and a beam current of approximately $25 \mathrm{nA}$. Counting times were $30-70 \mathrm{~s}$, and the standards were natural minerals. Representative analyses are given in Tables 1-4.

\section{Olivine}

Olivine is present in the lower suite of Hole 794D and the upper suite of Hole 797C. The lowermost sample recovered by Hole 794C was a chilled marginal facies containing microphenocrysts of plagioclase olivine, and chromian spinel; however, this olivine was totally replaced by secondary minerals. Olivine is present throughout the lower part of Hole 794D as a phenocryst and groundmass phase, which compositionally ranges between $\mathrm{Fo}_{83}$ and $\mathrm{Fo}_{75}$ (Fig. 1; Table 1). Although there are indications that olivine may be a phenocryst phase in the lower part of the upper suite at Site 794, this phase was not present, or preserved, in the few samples examined during this study. The olivines in the upper suite at Site 797 range between $\mathrm{Fo}_{89}$ and $\mathrm{Fo}_{79}$; within that obtained experimentally in 1 atmosphere melting
Table 1. Representative analyses of olivine.

\begin{tabular}{|c|c|c|c|c|c|c|c|}
\hline \multirow{2}{*}{$\begin{array}{l}\text { Hole } \\
\text { Core/section }\end{array}$} & \multicolumn{2}{|c|}{$128-794 D$} & \multicolumn{5}{|c|}{$127-797 \mathrm{C}$} \\
\hline & $13 R-1$ & $13 R-1$ & $12 R-2$ & $12 \mathrm{R}-2$ & $12 \mathrm{R}-2$ & $12 \mathrm{R}-2$ & $24 \mathrm{R}-6$ \\
\hline \multirow[t]{2}{*}{ Sample $(\mathrm{cm})$} & $87-91$ & $87-91$ & $81-83$ & $81-83$ & $74-79$ & $74-79$ & $40-41$ \\
\hline & \multicolumn{2}{|c|}{ lower suite } & \multicolumn{5}{|c|}{ upper suite } \\
\hline
\end{tabular}

\begin{tabular}{lrrrrrrr} 
& & & & & & & \\
$\mathrm{SiO}_{2}$ & 38.71 & 37.47 & 40.99 & 40.33 & 39.79 & 39.07 & 39.22 \\
$\mathrm{TiO}_{2}$ & 0.00 & 0.03 & 0.00 & 0.00 & 0.00 & 0.00 & 0.00 \\
$\mathrm{Al}_{2} \mathrm{O}_{3}$ & 0.06 & 0.02 & 0.09 & 0.08 & 0.03 & 0.05 & 0.05 \\
$\mathrm{FeO}$ & 15.93 & 23.11 & 10.97 & 12.70 & 14.90 & 16.92 & 19.55 \\
$\mathrm{MnO}$ & 0.19 & 0.35 & 0.18 & 0.19 & 0.20 & 0.23 & 0.31 \\
$\mathrm{MgO}$ & 44.71 & 38.98 & 48.90 & 47.28 & 45.33 & 43.19 & 41.67 \\
$\mathrm{CaO}$ & 0.30 & 0.39 & 0.31 & 0.32 & 0.37 & 0.43 & 0.33 \\
$\mathrm{Cr}_{2} \mathrm{O}_{3}$ & 0.05 & 0.07 & 0.08 & 0.06 & 0.07 & 0.07 & 0.05 \\
$\mathrm{Total}$ & 99.95 & 100.42 & 101.52 & 100.96 & 100.69 & 99.96 & 101.18 \\
Fo mol\% & 83.3 & 75.0 & 88.8 & 86.9 & 84.4 & 82.0 & 79.2 \\
\hline
\end{tabular}

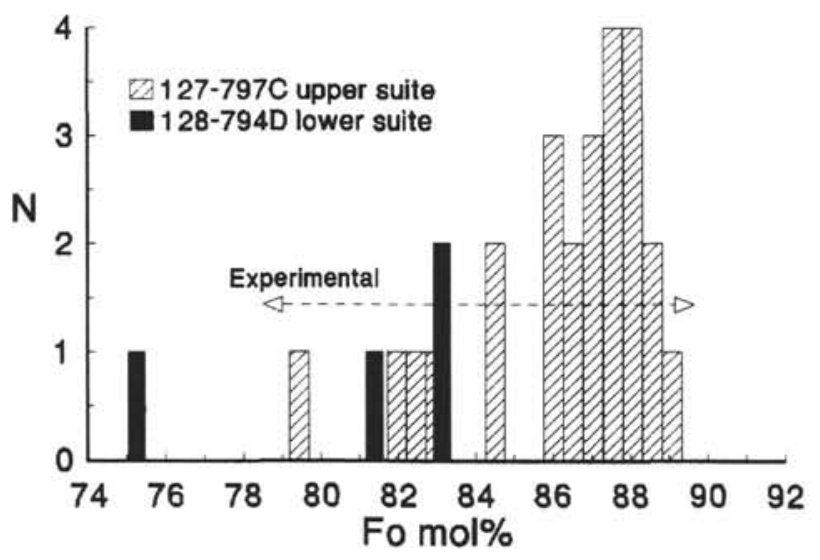

Figure 1. Histogram of mol\% Fo of olivine. Olivine is only preserved in rocks from Hole 127-797C (upper suite) and Hole 128-794D (lower suite; cf. Appendix). The compositional range for 1 atmosphere, experimental olivine is shown as indicated for a sample from Hole 127-797C (Thy, this volume).

experiments on a sample from the same suite of rocks (Thy, this volume; Fig. 1).

\section{Plagioclase}

Plagioclase is preserved to various degrees in all the examined rocks. Compositionally, this phase ranges between $\mathrm{An}_{91}$ and $\mathrm{An}_{42}$ (Table 2; Fig. 2). The upper suite at Site 794 contains relatively calcic plagioclase phenocrysts $\left(\mathrm{An}_{91-85}\right)$, while the microphenocrysts to groundmass phases in the same rocks range between $\mathrm{An}_{82}$ and $\mathrm{An}_{56}$ (Fig. $3 \mathrm{~A}$ ). Except for the presence of calcic phenocrysts in the upper few sills, there are no significant differences between these and remaining parts of the upper suite (Fig. 3A). Calcic plagioclase phenocrysts are not found in any of the other rocks examined. The lower suite at Site 794 contains relatively sodic and potassium-poor plagioclases $\left(\mathrm{An}_{74-42}\right.$; Fig. $\left.2 \mathrm{~A}\right)$. The plagioclases of Site 795 show large variations with the relatively sodic varieties found in the andesites of the upper suite. Plagioclases in the lower basaltic suite range between $A n_{78}$ and $A n_{65}$ (Fig. 2B). The plagioclases of Site 797 are, except for Section 127-797C-34R-1, clearly separated into two groups: the olivine-bearing upper suite that contains plagioclase with An mol\% between 80 and 60 and low potassium (Fig. 2C) and the lower, relatively evolved, suite that contains relatively sodic and potassic plagioclase. The sample analyzed from Section 127-797C-34R-1 most likely belongs to the upper suite. 

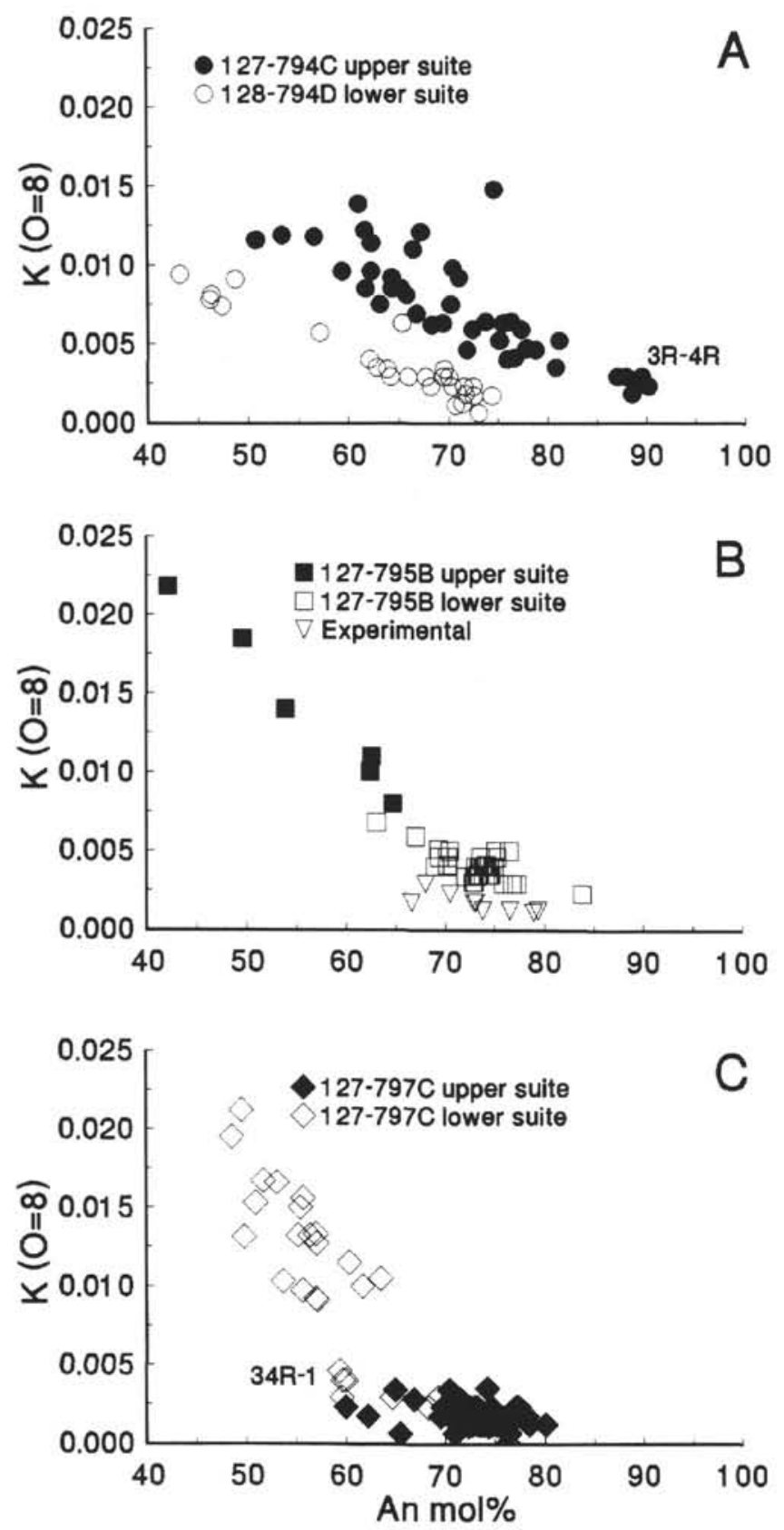

Figure 2. Variation in $\mathrm{K}(\mathrm{O}=8)$ vs. mol\% An of plagioclase. A. Hole $127-794 \mathrm{C}$ and Hole 128-794D. B. Hole 127-795B. C. Hole 127-797C. Section 34R-1 may, judging from the plagioclase compositions, belong to the upper suite.

\section{Augite}

Ca-rich pyroxene occurs in all groups of rocks; however, Ca-poor pyroxene was not encountered in any of the examined rocks, neither as a phenocryst nor as a groundmass phase. The pyroxenes are mostly salites and augites (Fig. 4; Table 3) and show wide compositional variations, with a general increase in $\mathrm{Ti}$ and $\mathrm{Na}$ with decreasing $\mathrm{Mg} /(\mathrm{Mg}+\mathrm{Fe}$ ) (Figs. $\mathrm{AA}$ and $\mathrm{B})$. Calculated $\mathrm{Al}^{\mathrm{iv}}$ is highly correlated with $\mathrm{Ti}$ for most individual suites (Fig. 6), but show poor correlation with $\mathrm{Mg} /(\mathrm{Mg}+\mathrm{Fe})$ (Fig. $5 \mathrm{C})$. The amount of $\mathrm{Fe}^{3+}$ in the augites can be estimated by charge balancing the cation substitutions (Papike et al., 1974). This suggests fairly constant amounts of $\mathrm{Fe}^{3+}$ of about 0.04 cations per 6 oxygens for the majority of the analyzed augites; this value is equivalent to an average $\mathrm{Fe}^{3+} /\left(\mathrm{Fe}^{2+}+\mathrm{Fe}^{3+}\right)$ of 0.17 .
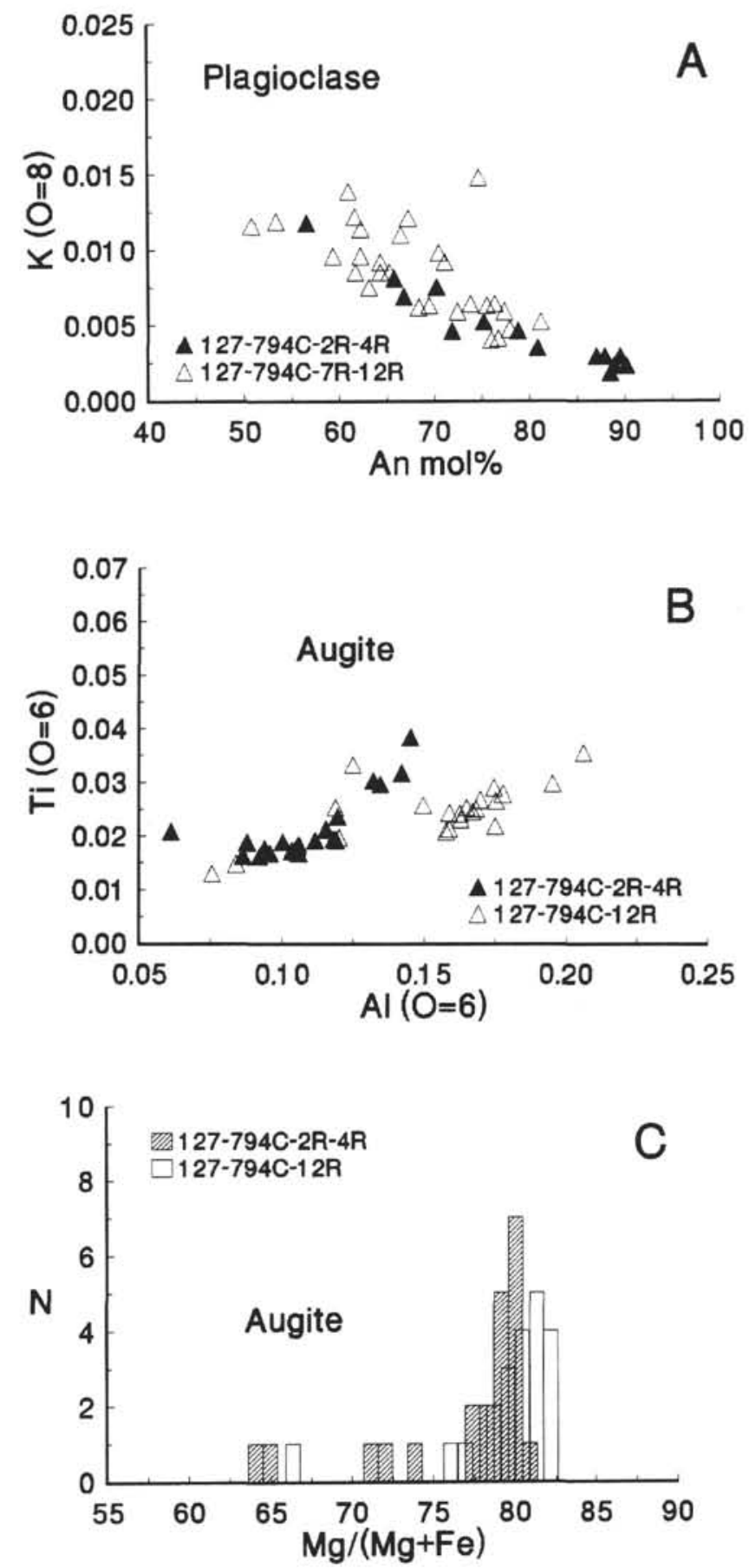

Figure 3. Summary of mineral compositions of Hole 794C, upper suite. A. Variation in $\mathrm{K}(\mathrm{O}=8)$ vs. mol\% An of plagioclase. B. Ti vs. $\mathrm{Al}(\mathrm{O}=6)$ for augite. C. Histograms of $\mathrm{Mg} / \mathrm{Mg}+\mathrm{Fe})$ for augite with all iron as $\mathrm{Fe}^{2+}$.

In general, there is a tendency toward high $\mathrm{Ti}$ and $\mathrm{Na}$ contents for augites with high $\mathrm{Fe} /(\mathrm{Fe}+\mathrm{Mg}$ ) ratios (Figs. 6-8). The upper suites at Site 794 have augites with $\mathrm{Ti} / \mathrm{Al}^{\mathrm{iv}}$ ratios mostly between $1 / 3$ and $1 / 6$. For pyroxenes in the lower suite, the $\mathrm{Ti} / \mathrm{Al}^{\mathrm{iv}}$ ratios appear higher (1/2 to $\left.1 / 4\right)$, but show overlap with the upper suite (Fig. $6 \mathrm{~A}$ ). The $\mathrm{Fe} /(\mathrm{Mg}+\mathrm{Fe}$ ) ratios and $\mathrm{Na}$ contents for the augites of the lower suite tend to be relatively low compared to the upper part of the core at Site 794 (Figs. 7A and 8A).

The augites of the upper few calcic plagioclase-bearing sills at Site 794 have lower $\mathrm{Al}$ contents than the rest of the augites in this suite (Fig. 3B). In addition, there is a tendency toward lower 


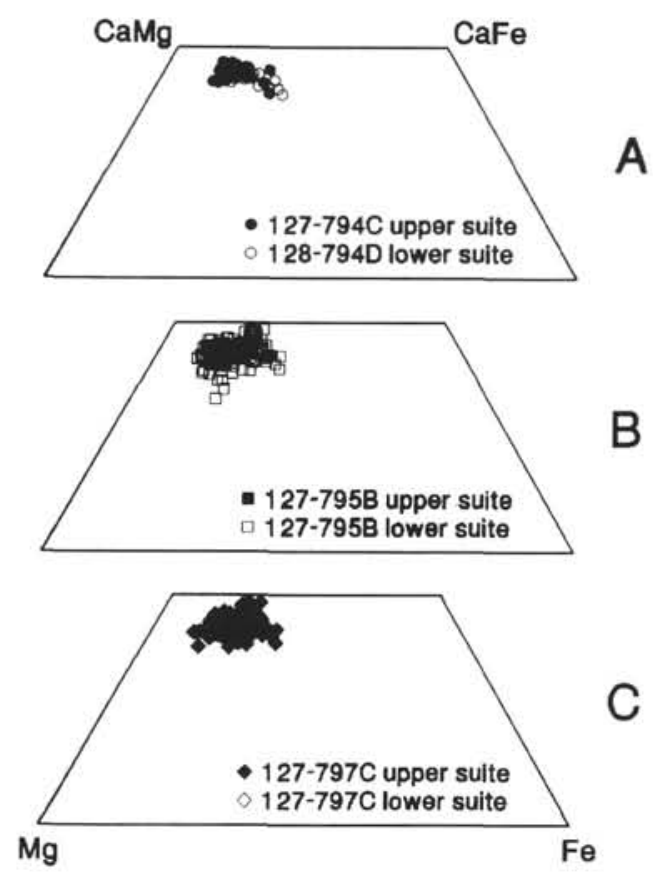

Figure 4. Augite compositions shown in the $\mathrm{Mg}-\mathrm{Ca}-\mathrm{Fe}$ diagram. All iron is calculated as $\mathrm{Fe}^{2+}$. A. Hole 127-794C and Hole 128-794D. B. Hole 127-795B. C. Hole 127-797C.
$\mathrm{Mg} /(\mathrm{Mg}+\mathrm{Fe}$ ) ratios for the former (Fig. 3C). The augites of the upper sills are medium-grained, dominantly subophitic, while the augites of the lower sills/flows are finer grained, intersertal to intergranular. The textures thus suggest variation in cooling rate with the upper sills having cooled relatively slow compared to the lower sills. The observed variation in augite composition would appear consistent with the expected effects of variable cooling rates (Coish and Taylor, 1979; Grove and Bence, 1979). The differences in augite compositions between the upper and the lower sills/flows of the upper suite at Site 794, therefore, do not necessarily reflect differences in magma compositions.

The augites of the upper andesitic suite at Site 795 have relatively high $\mathrm{Ti} / \mathrm{Al}^{\mathrm{iv}}$ ratios of $1 / 3$ to $1 / 5$ in contrast to the lower basaltic suite, which has very low Ti contents (Ti/Al ${ }^{\text {iv }}<1 / 5$; Fig. $\left.6 \mathrm{~B}\right)$. This is the opposite of what would have been expected from rock compositions, where the andesites of the upper suite have the lowest $\mathrm{TiO}_{2}$ (Tamaki, Pisciotto, Allan, et al., 1990). The majority of the augites from the basalts of Site 795 shows relatively low $\mathrm{Al}$ and $\mathrm{Ti}$ contents, very similar to those of the upper few sills at Site 794. This may in part be a reflection of the phenocrystic and microphenocrystic nature of most of these augites. The Na content of the augites of the basalts is significantly lower than for the andesites (Fig. $8 \mathrm{~B})$, while $\mathrm{Mg} /(\mathrm{Mg}+\mathrm{Fe}$ ) ratios are the highest found for any of the Japan Sea rocks (Fig. 7B).

The augites at Site 797 show highly correlated $\mathrm{Ti}$ and $\mathrm{Al}^{\mathrm{iv}}$ contents with $\mathrm{Ti} / \mathrm{Al}^{\mathrm{iv}}$ ratios between $1 / 2$ and $1 / 5$, without clear differences between the two suites (Fig. 6C). The majority of the analyzed grains is skeletal groundmass phases (PI. 1,6), which may explain the large variation observed in $\mathrm{Ti}$ and $\mathrm{Al}$ (Fig. 6C) in contrast to the more restricted ranges observed in experiments on a Site 797 sill (Thy, this

Table 2. Representative analyses of plagioclase.

\begin{tabular}{|c|c|c|c|c|c|c|c|c|c|c|c|c|c|c|}
\hline \multirow{3}{*}{$\begin{array}{l}\text { Hole } \\
\text { Core/section } \\
\text { Sample }(\mathrm{cm})\end{array}$} & \multicolumn{3}{|c|}{$128-794 \mathrm{D}$} & \multicolumn{6}{|c|}{$127-794 \mathrm{C}$} & \multicolumn{3}{|c|}{ 127-795B (upper suite) } & \multicolumn{2}{|c|}{ 127-795B (lower suite) } \\
\hline & 17R-1 & 13R-1 & $17 \mathrm{R}-1$ & $4 \mathrm{R}-1$ & $3 R-1$ & $2 \mathrm{R}-1$ & $12 \mathrm{R}-3$ & $8 R-1$ & $8 \mathrm{R}-1$ & $34 \mathrm{R}-1$ & $34 \mathrm{R}-1$ & $34 R-1$ & $36 \mathrm{R}-2$ & $41 R-1$ \\
\hline & $85-86$ & $87-91$ & $85-86$ & $44-46$ & $123-125$ & $77-79$ & $71-73$ & $4-5$ & $4-5$ & $46-47$ & $46-47$ & $46-47$ & $49-51$ & $107-109$ \\
\hline $\mathrm{SiO}_{2}$ & 50.36 & 52.08 & 56.60 & 45.85 & 46.18 & 48.35 & 51.01 & 52.49 & 55.45 & 51.88 & 54.91 & 56.98 & 50.05 & 51.31 \\
\hline $\mathrm{TiO}_{2}$ & 0.08 & 0.06 & 0.13 & 0.00 & 0.00 & 0.02 & 0.03 & 0.07 & 0.07 & 0.09 & 0.15 & 0.09 & 0.02 & 0.04 \\
\hline $\mathrm{Al}_{2} \mathrm{O}_{3}$ & 32.37 & 30.55 & 27.58 & 34.90 & 34.73 & 32.13 & 30.91 & 29.90 & 28.80 & 29.95 & 29.01 & 26.98 & 31.16 & 31.12 \\
\hline $\mathrm{FeO}$ & 0.38 & 0.52 & 0.70 & 0.49 & 0.43 & 0.57 & 0.59 & 0.68 & 0.81 & 0.95 & 0.71 & 0.72 & 0.73 & 0.83 \\
\hline $\mathrm{MgO}$ & 0.20 & 0.21 & 0.09 & 0.13 & 0.19 & 0.11 & 0.17 & 0.16 & 0.14 & 0.47 & 0.15 & 0.09 & 0.17 & 0.25 \\
\hline $\mathrm{CaO}$ & 14.98 & 13.00 & 9.79 & 18.62 & 18.52 & 16.48 & 14.47 & 12.82 & 10.92 & 12.66 & 11.27 & 8.68 & 15.34 & 14.37 \\
\hline $\mathrm{Na}_{2} \mathrm{O}$ & 3.11 & 4.21 & 5.92 & 1.09 & 1.25 & 2.12 & 3.24 & 4.05 & 5.14 & 4.06 & 5.17 & 6.36 & 2.76 & 3.45 \\
\hline $\mathrm{K}_{2} \mathrm{O}$ & 0.04 & 0.06 & 0.13 & 0.04 & 0.04 & 0.06 & 0.17 & 0.13 & 0.21 & 0.19 & 0.25 & 0.38 & 0.08 & 0.08 \\
\hline Total & 101.52 & 100.69 & 100.94 & 101.12 & 101.34 & 99.84 & 100.59 & 100.30 & 101.54 & 100.25 & 101.62 & 100.28 & 100.31 & 101.45 \\
\hline An mol\% & 72.5 & 62.8 & 47.4 & 90.2 & 88.9 & 80.8 & 70.5 & 63.1 & 53.3 & 62.6 & 53.9 & 42.1 & 75.1 & 69.4 \\
\hline Or mol\% & 0.2 & 0.4 & 0.8 & 0.2 & 0.2 & 0.4 & 1.0 & 0.8 & 1.2 & 1.1 & 1.4 & 2.2 & 0.5 & 0.5 \\
\hline
\end{tabular}

Table 3. Representative analyses of augite. ${ }^{a}$

\begin{tabular}{|c|c|c|c|c|c|c|c|c|c|c|c|c|c|}
\hline \multirow{3}{*}{$\begin{array}{l}\text { Hole } \\
\text { Core/section } \\
\text { Sample }(\mathrm{cm})\end{array}$} & \multicolumn{6}{|c|}{ 128-794D (lower suite) } & \multicolumn{7}{|c|}{ 127-794C (upper suite) } \\
\hline & $13 R-1$ & $13 \mathrm{R}-1$ & $17 \mathrm{R}-1$ & $17 \mathrm{R}-1$ & $20 \mathrm{R}-1$ & $20 \mathrm{R}-1$ & $3 R-1$ & $3 R-1$ & $4 \mathrm{R}-1$ & $12 \mathrm{R}-2$ & $12 \mathrm{R}-3$ & $12 \mathrm{R}-3$ & $12 \mathrm{R}-4$ \\
\hline & $87-91$ & $87-91$ & $85-86$ & $85-86$ & $23-24$ & $23-24$ & $123-125$ & $123-125$ & $44-46$ & $133-135$ & $71-73$ & $71-73$ & $85-87$ \\
\hline $\mathrm{SiO}_{2}$ & 47.74 & 48.40 & 49.44 & 49.02 & 48.44 & 49.54 & 51.73 & 49.45 & 51.85 & 50.08 & 50.84 & 49.65 & 52.90 \\
\hline $\mathrm{TiO}_{2}$ & 2.10 & 1.83 & 1.36 & 1.54 & 2.18 & 1.56 & 0.60 & 1.34 & 0.58 & 1.07 & 0.87 & 1.16 & 0.47 \\
\hline $\mathrm{Al}_{2} \mathrm{O}_{3}$ & 5.04 & 3.59 & 3.54 & 4.24 & 5.29 & 2.97 & 2.43 & 3.23 & 1.97 & 4.47 & 3.62 & 2.78 & 1.74 \\
\hline $\mathrm{FeO}^{*}$ & 9.14 & 10.54 & 8.91 & 7.66 & 8.97 & 11.69 & 6.83 & 11.67 & 7.52 & 6.70 & 6.55 & 12.00 & 6.34 \\
\hline $\mathrm{MnO}$ & 0.20 & 0.22 & 0.22 & 0.19 & 0.20 & 0.29 & 0.12 & 0.26 & 0.21 & 0.14 & 0.15 & 0.29 & 0.29 \\
\hline $\mathrm{MgO}$ & 13.30 & 12.72 & 14.32 & 14.19 & 13.65 & 13.58 & 15.79 & 11.98 & 15.75 & 14.92 & 15.03 & 13.02 & 16.93 \\
\hline $\mathrm{CaO}$ & 20.88 & 20.58 & 21.12 & 22.11 & 20.78 & 19.89 & 22.29 & 21.12 & 21.86 & 22.38 & 21.65 & 20.08 & 21.13 \\
\hline $\mathrm{Na}_{2} \mathrm{O}$ & 0.41 & 0.44 & 0.40 & 0.33 & 0.48 & 0.40 & 0.26 & 0.36 & 0.27 & 0.25 & 0.29 & 0.36 & 0.22 \\
\hline $\mathrm{Cr}_{2} \mathrm{O}_{3}$ & 0.34 & 0.25 & 0.22 & 0.21 & 0.37 & 0.04 & 0.22 & 0.02 & 0.05 & 0.22 & 0.29 & 0.03 & 0.10 \\
\hline Total & 99.15 & 98.57 & 99.53 & 99.49 & 100.36 & 99.96 & 100.27 & 99.43 & 100.06 & 100.23 & 99.29 & 99.37 & 100.12 \\
\hline En mol\% & 39.8 & 38.1 & 41.5 & 41.3 & 40.6 & 39.4 & 44.3 & 35.5 & 44.1 & 42.9 & 43.9 & 38.1 & 47.5 \\
\hline Fs mol\% & 15.3 & 17.7 & 14.5 & 12.5 & 15.0 & 19.1 & 10.8 & 19.4 & 11.8 & 10.8 & 10.7 & 19.7 & 10.0 \\
\hline Wo mol\% & 44.9 & 44.2 & 44.0 & 46.2 & 44.4 & 41.5 & 44.9 & 45.1 & 44.1 & 46.3 & 45.4 & 42.2 & 42.5 \\
\hline
\end{tabular}

${ }^{\mathrm{a}} \mathrm{FeO}$ and $\mathrm{Fe}_{2} \mathrm{O}_{3}$ are calculated according to spinel stoichiometry. 
volume). The augites of the lower suite contain significantly lower $\mathrm{Na}$ than those of the upper suite (Fig. 8C), without differences in $\mathrm{Mg} /(\mathrm{Mg}+\mathrm{Fe})$ ratios (Fig. 7C).

The mineral compositions have been recast into the dominant non-quadrilateral, end-member molecules in Figure 9. The results of this calculation reflect the cation abundances and calculation conventions. All Na is calculated as $\mathrm{NaFe}^{3+} \mathrm{Si}_{2} \mathrm{O}_{6}$, the remaining $\mathrm{Fe}^{3+}$ is calculated as $\mathrm{CaFe}^{3+} \mathrm{Al}_{2} \mathrm{SiO}_{6}$. Subsequently, all $\mathrm{Ti}$ is calculated as $\mathrm{CaTiAlSiO}_{6}$ and remaining $\mathrm{Al}$ is calculated as $\mathrm{CaAl}_{2} \mathrm{SiO}_{6}$. Following this calculation scheme, other non-quadrilateral, end-member molecules are rarely present in significant amounts in the pyroxenes. It is evident from Figure 9 that the main variation is due to the variable $\mathrm{Na}$ and $\mathrm{Ti}$ contents. The extreme variation in calculated $\mathrm{CaFe}^{3+} \mathrm{Al}_{2} \mathrm{O}_{6}$ may in part reflect the uncertainty in the calculations; the only exception is the andesite flow from Site 795, whose augites contain relatively high calculated $\mathrm{Fe}^{3+}$, in excess of that allocated to $\mathrm{Na}$.

\section{Spinels and Ilmenite}

The opaque minerals are dominantly magnetite with minor amounts of ilmenite. The magnetite is a titanomagnetite with $24 \%-48 \%$ ulvöspinel and the ilmenite contains $4 \%-9 \%$ hematite (Table 4). There is little difference in the compositions of the $\mathrm{Fe}$ - $\mathrm{Ti}$ oxide minerals between the individual suites. Secondary magnetite appears to contain high amounts of $\mathrm{MnO}$ (Table 4). Chromian spinel occurs in some olivine-bearing rocks as inclusions in olivine and in the groundmass (Table 4). Allan (this volume) discusses the composition of chromian spinels in more detail.

\section{DISCUSSION}

\section{Petrography and Mineral Compositions}

The drilled sills and flows can be grouped into petrographically and compositionally distinct suites. Site 794 drilled an upper suite composed of a few upper sills of highly plagioclase phyric basaltic sills, while the rest of the suite is composed of aphyric basaltic sills/flows with marginal zones of sparsely plagioclase or plagioclase and olivine phyric basalts. The uppermost few sills contain calcic plagioclase $\left(\mathrm{An}_{91-85}\right)$ phenocrysts, but except for the presence of these, the upper suite appears petrographically homogeneous. Olivine has not been analyzed from the upper suite in this study, although it has been reported in primitive sills (Tamaki, Pisciotto, Allan, et al., 1990; Ingle, Suyehiro, von Breymann, et al., 1990). A lower suite at Site 794 is composed of aphyric to sparsely plagioclase $\left(\mathrm{An}_{<74}\right)$ and olivine phyric basaltic sills/flows. Olivine $\left(\mathrm{Fo}_{<83}\right)$ appears as phenocryst and groundmass phases. This lower suite has groundmass plagioclases with significantly lower contents of potassium for similar An contents, and augites with higher $\mathrm{Ti} / \mathrm{Al}^{\mathrm{iv}}$ ratios, sodium contents, and $\mathrm{Fe} /(\mathrm{Mg}+\mathrm{Fe})$ ratios compared to the upper suite (Figs. 3C and $6 \mathrm{~A}-8 \mathrm{~A}$ ).

The highly plagioclase phyric nature of the few upper sills at Site 794 may in part be an effect of crystal accumulation (Allan and Gorton, this volume). Low-pressure, anhydrous, equilibrium, plagioclase phenocrysts should be significantly less calcic $\left(\sim \mathrm{An}_{72}\right.$; Nielsen, 1988; Glazner, 1984) than observed. The presence of calcic plagioclase has been taken to indicate crystallization under elevated water

Table 2 (continued).

\begin{tabular}{|c|c|c|c|c|c|c|c|c|c|c|}
\hline \multirow{3}{*}{$\begin{array}{l}\text { Hole } \\
\text { Core/section } \\
\text { Sample }(\mathrm{cm})\end{array}$} & \multicolumn{4}{|c|}{ 127-797C (upper suite) } & \multicolumn{6}{|c|}{ 127-797C (lower suite) } \\
\hline & $13 \mathrm{R}-2$ & $24 \mathrm{R}-6$ & $24 \mathrm{R}-6$ & $19 \mathrm{R}-2$ & $34 \mathrm{R}-1$ & $34 \mathrm{R}-1$ & $31 \mathrm{R}-2$ & $45 \mathrm{R}-1$ & $29 \mathrm{R}-1$ & $29 \mathrm{R}-1$ \\
\hline & $70-72$ & $40-41$ & $40-41$ & $42-44$ & $31-33$ & $31-33$ & $36-38$ & $49-50$ & 93-94 & 93-94 \\
\hline $\mathrm{SiO}_{2}$ & 48.75 & 49.70 & 52.81 & 53.77 & 50.60 & 53.84 & 55.06 & 54.55 & 55.81 & 55.93 \\
\hline $\mathrm{TiO}_{2}$ & 0.00 & 0.00 & 0.05 & 0.05 & 0.00 & 0.00 & 0.07 & 0.10 & 0.07 & 0.12 \\
\hline $\mathrm{Al}_{2} \mathrm{O}_{3}$ & 32.92 & 32.93 & 30.76 & 29.46 & 31.96 & 29.75 & 28.91 & 28.87 & 27.36 & 27.69 \\
\hline $\mathrm{FeO}$ & 0.36 & 0.33 & 0.54 & 0.57 & 0.59 & 0.48 & 0.65 & 0.72 & 1.00 & 0.80 \\
\hline $\mathrm{MgO}$ & 0.24 & 0.19 & 0.18 & 0.13 & 0.09 & 0.04 & 0.16 & 0.12 & 0.36 & 0.10 \\
\hline $\mathrm{CaO}$ & 16.48 & 15.69 & 13.17 & 12.37 & 14.60 & 12.23 & 12.34 & 11.27 & 10.29 & 10.10 \\
\hline $\mathrm{Na}_{2} \mathrm{O}$ & 2.25 & 2.64 & 3.88 & 4.54 & 3.29 & 4.56 & 4.36 & 4.86 & 5.13 & 5.45 \\
\hline $\mathrm{K}_{2} \mathrm{O}$ & 0.02 & 0.03 & 0.06 & 0.04 & 0.04 & 0.05 & 0.20 & 0.17 & 0.29 & 0.37 \\
\hline Total & 101.02 & 101.51 & 101.45 & 100.93 & 101.17 & 100.95 & 100.75 & 100.66 & 100.31 & 100.56 \\
\hline An mol\% & 80.1 & 76.5 & 65.0 & 60.0 & 70.9 & 59.5 & 60.3 & 55.6 & 51.7 & 49.5 \\
\hline Or mol\% & 0.1 & 0.2 & 0.4 & 0.2 & 0.2 & 0.3 & 1.2 & 1.0 & 1.7 & 2.2 \\
\hline
\end{tabular}

Table 3 (continued).

\begin{tabular}{|c|c|c|c|c|c|c|c|c|c|c|c|c|c|}
\hline \multirow{3}{*}{$\begin{array}{l}\text { Hole } \\
\text { Core/section } \\
\text { Sample }(\mathrm{cm})\end{array}$} & \multicolumn{3}{|c|}{ 127-795B (upper suite) } & \multicolumn{4}{|c|}{ 127-795B (lower suite) } & \multicolumn{6}{|c|}{ 127-797C (upper suite) } \\
\hline & $34 \mathrm{R}-1$ & $34 \mathrm{R}-1$ & $34 \mathrm{R}-1$ & $36 \mathrm{R}-2$ & $36 \mathrm{R}-2$ & $41 \mathrm{R}-1$ & $41 \mathrm{R}-1$ & $12 \mathrm{R}-2$ & $12 \mathrm{R}-4$ & 13R-2 & $21 \mathrm{R}-5$ & $21 R-5$ & $24 \mathrm{R}-6$ \\
\hline & $46-47$ & $46-47$ & $46-47$ & $49-51$ & 49-51 & $107-109$ & $107-109$ & $74-79$ & $35-37$ & $70-72$ & $101-103$ & $101-103$ & $40-41$ \\
\hline $\mathrm{SiO}_{2}$ & 47.34 & 48.47 & 48.81 & 52.22 & 53.45 & 52.51 & 50.25 & 49.16 & 46.55 & 49.37 & 51.69 & 53.44 & 51.13 \\
\hline $\mathrm{TiO}_{2}$ & 2.11 & 1.24 & 1.46 & 0.40 & 0.39 & 0.31 & 0.95 & 1.42 & 2.54 & 1.71 & 0.83 & 0.59 & 0.98 \\
\hline $\mathrm{Al}_{2} \mathrm{O}_{3}$ & 3.78 & 3.98 & 4.32 & 2.97 & 1.37 & 2.32 & 4.53 & 4.39 & 6.54 & 4.64 & 3.25 & 1.86 & 4.40 \\
\hline $\mathrm{FeO}^{*}$ & 12.60 & 7.84 & 9.02 & 5.75 & 9.61 & 5.47 & 7.91 & 9.23 & 8.11 & 8.38 & 7.50 & 7.07 & 6.03 \\
\hline $\mathrm{MnO}$ & 0.32 & 0.18 & 0.22 & 0.12 & 0.29 & 0.14 & 0.23 & 0.16 & 0.12 & 0.14 & 0.20 & 0.21 & 0.12 \\
\hline $\mathrm{MgO}$ & 12.59 & 15.56 & 14.52 & 16.58 & 17.20 & 16.33 & 14.95 & 12.53 & 12.56 & 13.40 & 15.27 & 16.13 & 15.11 \\
\hline $\mathrm{CaO}$ & 19.95 & 20.39 & 20.89 & 22.14 & 18.64 & 21.91 & 20.14 & 21.63 & 21.90 & 21.07 & $\quad 21.14$ & 20.86 & 21.89 \\
\hline $\mathrm{Na}_{2} \mathrm{O}$ & 0.47 & 0.39 & 0.36 & 0.23 & 0.16 & 0.20 & 0.25 & 0.51 & 0.51 & 0.44 & 0.37 & 0.30 & 0.38 \\
\hline $\mathrm{Cr}_{2} \mathrm{O}_{3}$ & 0.03 & 0.60 & 0.15 & 0.13 & 0.02 & 0.12 & 0.14 & 0.23 & 0.36 & 0.18 & 0.24 & 0.26 & 0.52 \\
\hline Total & 99.19 & 98.65 & 99.75 & 100.54 & 101.13 & 99.31 & 99.35 & 99.26 & 99.19 & 99.33 & 100.49 & 100.72 & 100.56 \\
\hline En mol\% & 37.0 & 45.0 & 42.0 & 46.4 & 47.8 & 46.5 & 44.1 & 37.7 & 38.2 & 40.3 & 44.0 & 46.0 & 44.1 \\
\hline Fs mol\% & 20.8 & 12.7 & 14.6 & 9.0 & 15.0 & $* 8.7$ & 13.1 & 15.6 & 13.9 & 14.1 & 12.1 & 11.3 & 9.9 \\
\hline Wo mol\% & 42.2 & 42.3 & 43.4 & 44.6 & 37.2 & 44.8 & 42.8 & 46.7 & 47.9 & 45.6 & 43.8 & 42.7 & 46.0 \\
\hline
\end{tabular}


pressure (Arculus and Wills, 1980), and is characteristic of arc lavas and gabbros (Beard, 1986). Marsh et al. (1990) have pointed out that available experimental data indicate unrealistic high water contents $(\sim 25 \mathrm{wt} \%)$ in order to be able to increase the composition of equilibrium plagioclase in basaltic magmas from $\mathrm{An}_{80}$ to $\mathrm{An}_{90}$. Consequently, they suggested that the same effect could be achieved by preferential loss of early-formed plagioclase crystals. This is in contrast to the trace element concentrations of the Japan Sea sills that suggest plagioclase accumulation (Allan and Gorton, this volume). The compositional gap between the calcic phenocrysts and the more sodic microphenocrysts and groundmass plagioclases (Fig. 3A) reflects a gap in crystallization history, suggesting that the sills solidified in two stages: at relatively high pressure and at lower pressure, probably after partial degassing. The fact that calcic plagioclase is present in the evolved rocks suggests that this phase accumulated, or was retained, during the evolution of the parental magma. This is consistent with the model proposed by S. Yamashita (pers. comm., 1991), who suggests a combination of crystal flotation and olivine fractionation at moderate pressures ( $2-3 \mathrm{kbar})$. The apparent lack of calcic plagioclase in the relatively primitive rocks, however, is a problem for cogenetic fractionation models.

The rocks recovered at Site 795 comprise an upper suite of plagioclase, augite, and magnetite phyric andesitic flows and a lower suite of plagioclase and augite phyric basaltic flows. Most of the mineral compositional variations observed within and between these suites reflect the wide variation in parental magma compositions. The augite phenocrysts of the basalts have the highest $\mathrm{Mg} /(\mathrm{Mg}+\mathrm{Fe})$ ratios found in any of the examined rocks. This is probably, in part, a reflection of their early crystallization as phenocrysts. It is, nevertheless, significant that the andesites contain augite phenocrysts with higher $\mathrm{Ti} / \mathrm{Al}^{\mathrm{iv}}$ ratios compared to the augites of the basalts (Fig. $6 \mathrm{~B}$ ). The calculated $\mathrm{Fe}^{3+}$ contents for the andesitic augites are relatively high compared to that calculated for the basaltic augites, and the availability of $\mathrm{Fe}^{3+}$ could control the coupled substitutions in the augites (e.g., Loucks, 1990). This could promote the $\mathrm{CaFe}^{3+} \mathrm{AlSiO}_{6}$ molecule in the andesitic augites, while the $\mathrm{CaTiAl}_{2} \mathrm{O}_{6}$ molecule would dominate in the basaltic augites of Site 795 (Fig. 9). The $\mathrm{Cr}$ and $\mathrm{Ti}$ contents of augites are significant lower for the basalts of Site 795 (Table 3), compared to augites from the other sites with similar $\mathrm{Mg} /(\mathrm{Mg}+\mathrm{Fe})$ ratios. Relatively low $\mathrm{Cr}$ and $\mathrm{Ti}$ contents are generally observed in arc augites (Nisbet and Pearce, 1977; Basaltic Volcanism Study Project, 1981) and are a reflection of parental arc tholeiitic magmas (Gill, 1981).

The sill/flow sequences of Site 797 can be divided into a dominantly lower suite of plagioclase phyric basalts and an upper suite of plagioclase

Table 3 (continued).

\begin{tabular}{|c|c|c|c|c|c|c|}
\hline \multirow{3}{*}{$\begin{array}{l}\text { Hole } \\
\text { Core/section } \\
\text { Sample }(\mathrm{cm})\end{array}$} & \multicolumn{6}{|c|}{ 127-797C (lower suite) } \\
\hline & $29 \mathrm{R}-1$ & 29R-1 & $31 \mathrm{R}-2$ & $31 R-2$ & $45 \mathrm{R}-1$ & $45 \mathrm{R}-1$ \\
\hline & 93-94 & $93-94$ & $36-38$ & $36-38$ & $49-50$ & $49-50$ \\
\hline $\mathrm{SiO}_{2}$ & 49.49 & 51.42 & 50.15 & 52.79 & 52.59 & 50.64 \\
\hline $\mathrm{TiO}_{2}$ & 1.50 & 0.74 & 1.41 & 0.52 & 0.67 & 1.04 \\
\hline $\mathrm{Al}_{2} \mathrm{O}_{3}$ & 3.18 & 2.29 & 3.30 & 2.03 & 1.90 & 1.51 \\
\hline $\mathrm{FeO}^{*}$ & 11.13 & 8.01 & 9.34 & 6.11 & 7.17 & 11.52 \\
\hline $\mathrm{MnO}$ & 0.27 & 0.21 & 0.20 & 0.19 & 0.12 & 0.31 \\
\hline $\mathrm{MgO}$ & 13.45 & 15.91 & 14.41 & 16.02 & 16.85 & 13.81 \\
\hline $\mathrm{CaO}$ & 19.20 & 20.48 & 20.14 & 20.79 & 20.29 & 20.06 \\
\hline $\mathrm{Na}_{2} \mathrm{O}$ & 0.37 & 0.31 & 0.40 & 0.33 & 0.25 & 0.35 \\
\hline $\mathrm{Cr}_{2} \mathrm{O}_{3}$ & 0.02 & 0.12 & 0.04 & 0.27 & 0.09 & 0.00 \\
\hline Total & 98.61 & 99.49 & 99.39 & 99.05 & 99.93 & 99.24 \\
\hline En mol\% & 40.2 & 45.3 & 42.2 & 46.6 & 47.5 & 39.8 \\
\hline Fs mol\% & 18.6 & 12.8 & 15.4 & 10.0 & 11.4 & 18.6 \\
\hline Wo mol\% & 41.2 & 41.9 & 42.4 & 43.4 & 41.1 & 41.6 \\
\hline
\end{tabular}
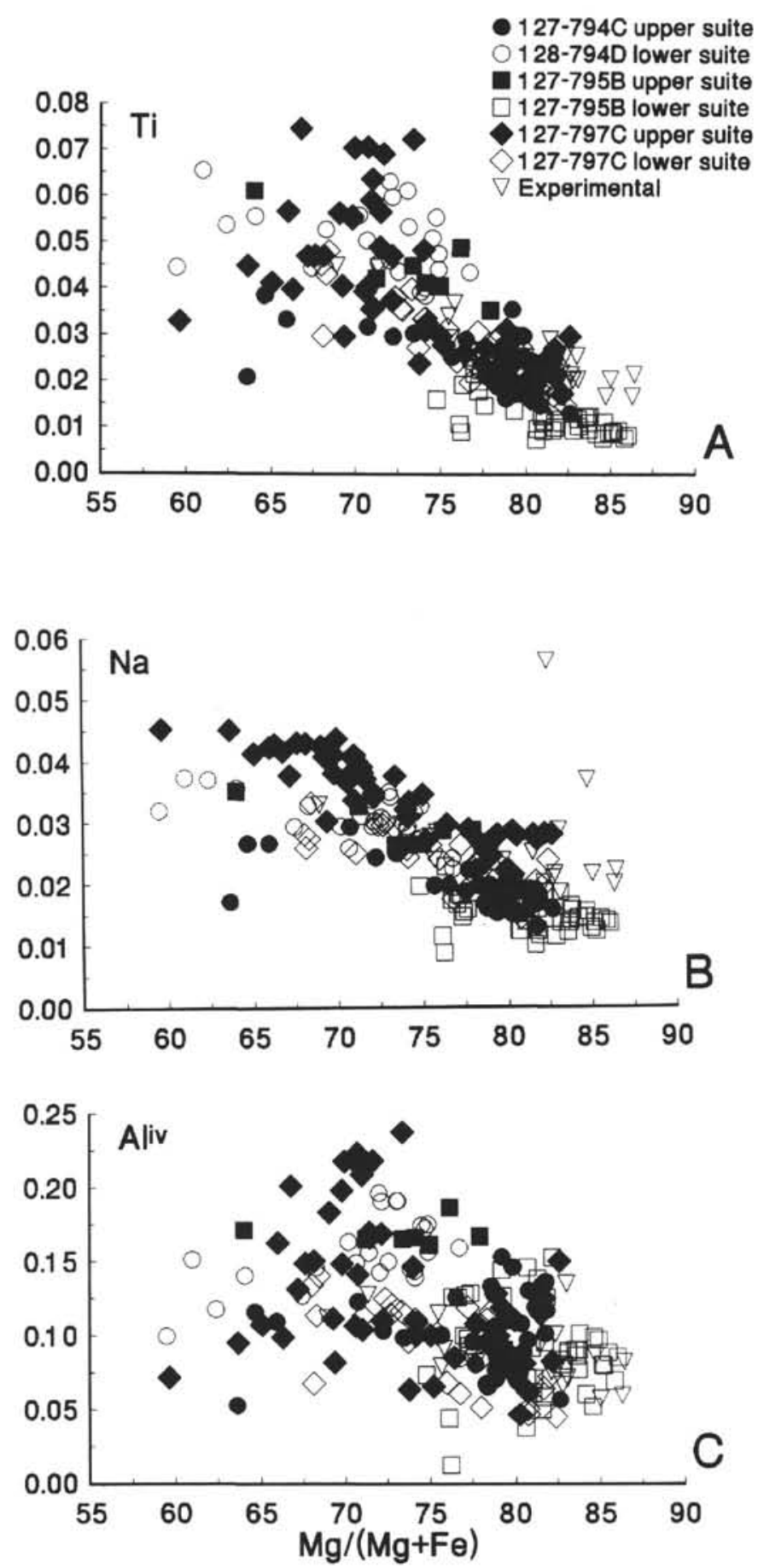

Figure 5. Minor element content of augites. All iron is calculated as $\mathrm{Fe}^{2+}$ and cations normalized to 6 oxygens. The experimental data are from Thy (this volume). A. Ti vs. $\mathrm{Mg} /(\mathrm{Mg}+\mathrm{Fe})$. B. $\mathrm{Na}$ vs. $\mathrm{Mg} /(\mathrm{Mg}+\mathrm{Fe})$. C. Calculated $\mathrm{Al}^{\mathrm{iv}}$ vs. $\mathrm{Mg} /(\mathrm{Mg}+\mathrm{Fe})$.

and olivine phyric basalts. However, there is, except for the presence of olivine in the upper suite, little difference between the two suites. The only exceptions are plagioclase, which contains significant higher potassium in the lower suite, and augite, which contains lower sodium for the lower suite compared to the upper suite. There are no clear differences in $\mathrm{Ti}$ content of augites for the two suites. 

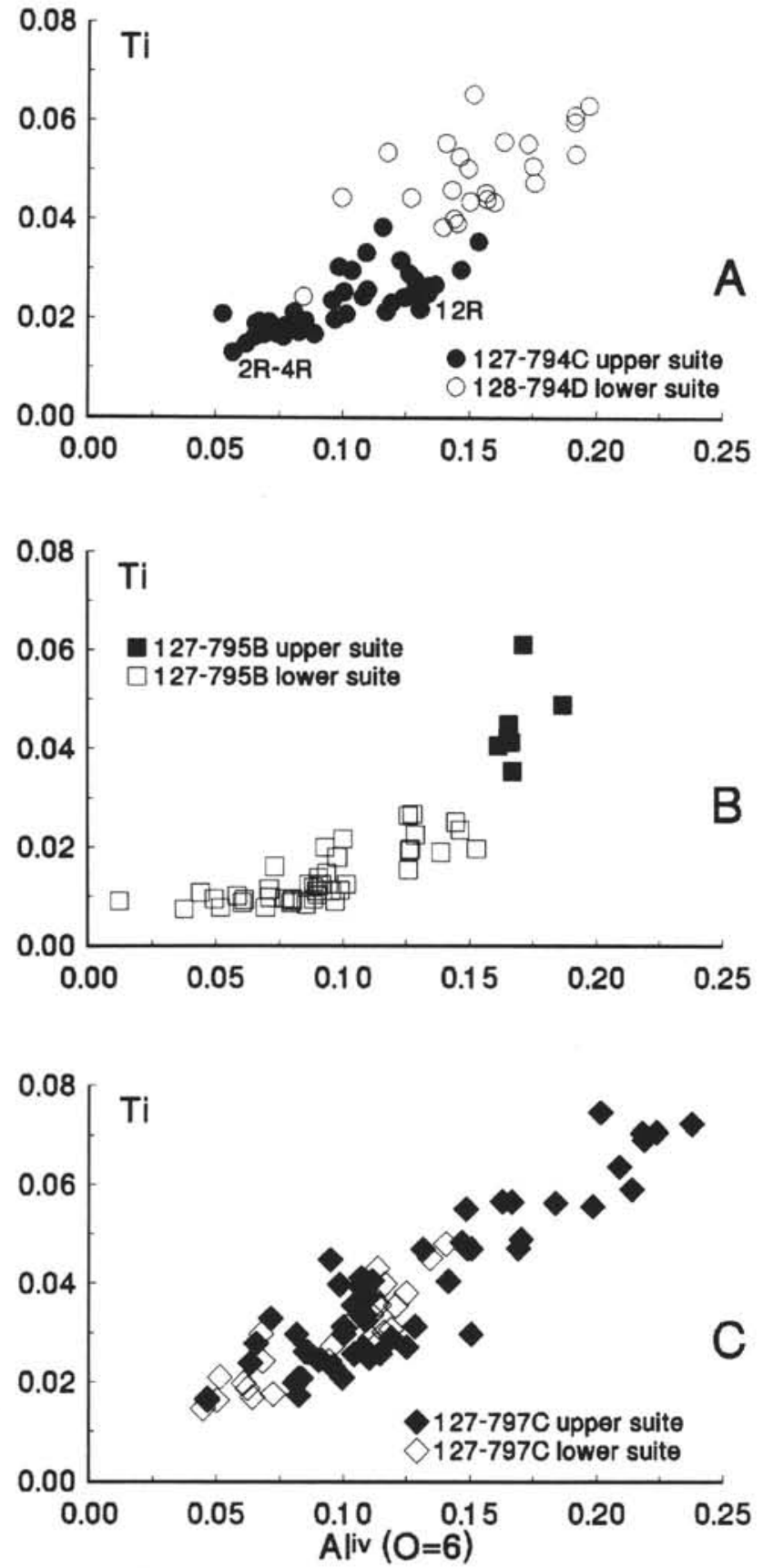

Figure 6. Ti vs. calculated $\mathrm{Al}^{\mathrm{iv}}(\mathrm{O}=6)$ for augite. A. Hole $127-794 \mathrm{C}$ and Hole 128-794D. There is a distinct difference between augites from Core 12R and those from Cores 2R-4R of the same suite. B. Hole 127-795B. C. Hole 127-797C.

The primitive olivine-bearing suites at Sites 794 and 797 both contain plagioclase with relatively low potassium contents and augites with relatively high sodium contents. On the other hand, the Site 794 suite has systematic lower $\mathrm{Mg} /(\mathrm{Mg}+\mathrm{Fe})$ of olivine and augite and lower An mol\% of plagioclase. These differences are a reflection of the more primitive nature of the olivine-bearing suite at Site 797. The olivine-free suites at both sites contain plagioclase with relatively high potassium content and augite with low sodium content. The most primitive rocks of the upper suite of Site 794 and those from Site 797 contain augites with approximately similar $\mathrm{Mg} /(\mathrm{Mg}+\mathrm{Fe})$ ratios, but the Site 794 suite reach significant more evolved lavas than seen for Site 797.
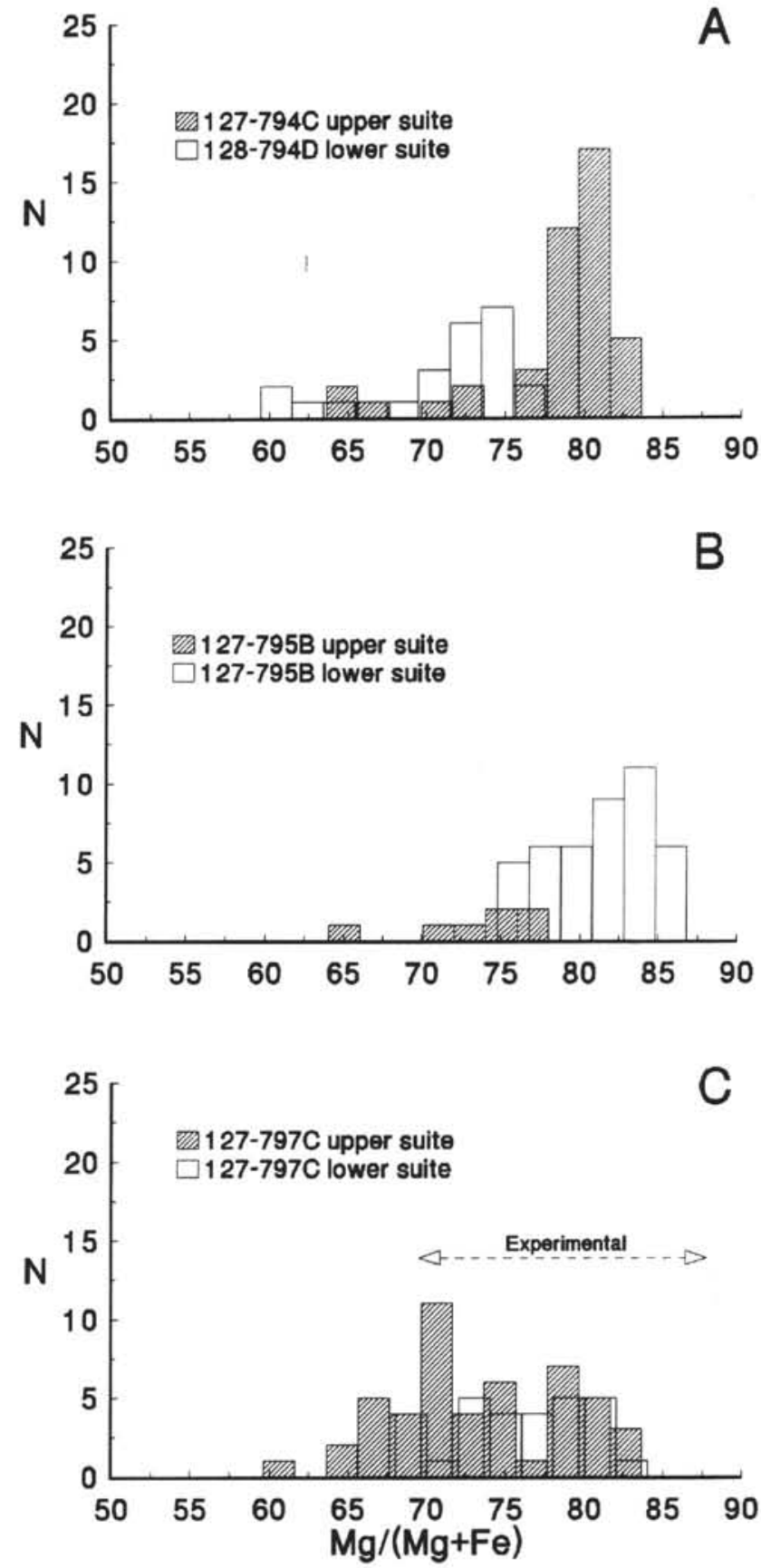

Figure 7. Histograms of $\mathrm{Mg} /(\mathrm{Mg}+\mathrm{Fe})$ of augite. A. Hole $127-794 \mathrm{C}$ and Hole 128-794D. B. Hole 127-795B. C. Hole 127-797C. The range in the experimental results is from Thy (this volume).

\section{Parental Magmas}

There are two district groups of magmas represented at Sites 794 and 797. One group is relatively primitive and contains olivine as phenocrysts as well as groundmass phases, the other group ranges from primitive olivine-bearing to evolved olivine-free sills. In conjunction with the experimental results summarized in Thy (this volume), the reported mineral compositions can be used to constrain parental magma compositions and the magmatic evolution during groundmass consolidation. The most magnesian olivines at Sites 794 and 797 are $\mathrm{Fo}_{83}$ and $\mathrm{Fo}_{89}$, respectively, which indicate $\mathrm{Mg} /(\mathrm{Mg}+\mathrm{Fe})$ 
Table 4. Representative analyses of chromian spinel, ilmenite, and magnetite. ${ }^{a}$

\begin{tabular}{|c|c|c|c|c|c|c|c|}
\hline \multirow{4}{*}{$\begin{array}{l}\text { Hole } \\
\text { Core/section } \\
\text { Sample }(\mathrm{cm})\end{array}$} & \multicolumn{2}{|c|}{ Chromian spinel } & \multicolumn{2}{|c|}{ Ilmenite } & \multicolumn{3}{|c|}{ Titanomagnetite } \\
\hline & $127-794 \mathrm{C}$ & $127-797 \mathrm{C}$ & $127-794 \mathrm{C}$ & $127-797 \mathrm{C}$ & $127-794 \mathrm{C}$ & $128-794 \mathrm{D}$ & $127-795 B$ \\
\hline & $12 \mathrm{R}-3$ & $24 \mathrm{R}-6$ & 2R-1 & 19R-2 & 2R-1 & 13R-1 & $34 \mathrm{R}-1$ \\
\hline & $71-73$ & $40-41$ & $77-78$ & $42-44$ & $77-79$ & $87-91$ & $46-47$ \\
\hline $\mathrm{SiO}_{2}$ & 0.14 & 0.04 & 0.04 & 0.00 & 0.10 & 0.09 & 0.17 \\
\hline $\mathrm{TiO}_{2}$ & 1.17 & 0.78 & 50.20 & 50.91 & 23.95 & 24.55 & 21.60 \\
\hline $\mathrm{Al}_{2} \mathrm{O}_{3}$ & 21.69 & 26.37 & 0.04 & 0.00 & 0.89 & 1.07 & 1.46 \\
\hline $\mathrm{FeO}$ & 18.27 & 18.87 & 42.24 & 42.89 & 50.16 & 52.01 & 44.84 \\
\hline $\mathrm{Fe}_{2} \mathrm{O}_{3}$ & 10.27 & 7.84 & 4.62 & 5.81 & 20.13 & 19.72 & 23.39 \\
\hline $\mathrm{MnO}$ & 0.22 & 0.22 & 0.87 & 1.27 & 1.97 & 1.30 & 5.78 \\
\hline $\mathrm{MgO}$ & 11.49 & 11.92 & 1.04 & 0.87 & 0.46 & 0.36 & 0.03 \\
\hline $\mathrm{CaO}$ & 0.36 & 0.02 & 0.17 & 0.04 & 0.03 & 0.02 & 0.07 \\
\hline $\mathrm{Cr}_{2} \mathrm{O}_{3}$ & 36.14 & 35.44 & 0.04 & 0.00 & 0.04 & 0.00 & 0.05 \\
\hline Total & 99.75 & 101.50 & 99.26 & 101.79 & 97.73 & 99.12 & 97.39 \\
\hline
\end{tabular}

ratios for the coexisting liquids of 0.56 and 0.68 . The most iron-rich olivines indicate $\mathrm{Mg} /(\mathrm{Mg}+\mathrm{Fe})$ ratios of 0.44 and 0.50 , respectively. A similar calculation for augite from the same suites of rocks indicates $\mathrm{Mg} /(\mathrm{Mg}+\mathrm{Fe})$ for the most magnesian, coexisting liquids of 0.45 and 0.54 , respectively, and ranging up to 0.31 and 0.36 (iron calculated as total $\mathrm{Fe}^{3+}$ ). These numbers suggest that olivine ceases to crystallize approximately when augite appears. For both the evolved suites, the most magnesian augites indicate coexisting liquids with $\mathrm{Mg} /(\mathrm{Mg}+\mathrm{Fe})$ $=0.54$. The appearance of augite, therefore, is relatively independent of whole rock compositions, with an exception of the augite phenocrysts in the Site 795 basalts, which coexist with liquids with $\mathrm{Mg} /(\mathrm{Mg}+\mathrm{Fe})=0.60$. These estimates assume that the distribution of $\mathrm{Fe}$ and $\mathrm{Mg}$ between augite and liquid are constant for all series and independent of the minor element substitutions. Although this assumption is questionable (Sack and Carmichael, 1984), it may in part be justified by the relatively constant $\mathrm{Ti} / \mathrm{Al}^{\mathrm{iv}}$ ratio of augites observed for the primitive series. Allan (this volume) evaluated the chromian spinels and estimated the $\mathrm{Mg} /(\mathrm{Mg}+\mathrm{Fe})$ ratios of the coexisting liquids to 0.62 to 0.66 for the Site 794 sills and 0.60 to 0.66 for the Site 797 sills; the former is significantly higher than obtained from the olivines.

The $\mathrm{TiO}_{2}$ content of the liquid can be qualitatively estimated from the $\mathrm{TiO}_{2}$ content of the augites assuming constant distribution coefficients $\left(\mathrm{D}^{\mathrm{TiO}_{2}}\right.$ (aug/liq) $=\mathrm{TiO}_{2}$ augite $/ \mathrm{TiO}_{2}$ liquid as wt $\%$ ). Average $\mathrm{D}^{\mathrm{TiO}}$ 's experimentally determined for a Site 797 olivine basalt (Thy, this volume) is 0.34 , which is only slightly higher than determined by Grove and Bryan (1983) for FAMOUS basalts (0.27) and observed for natural Galapagos rift basalts ( 0.31 ) by Perfit and Fornari (1983). Using the representative augite compositions of Table 3 , the estimates for the coexisting liquids would vary between 2 and $6 \mathrm{wt} \% \mathrm{TiO}_{2}$ for the olivine basalt suites and 1 and $4 \mathrm{wt} \% \mathrm{TiO}_{2}$ for the olivine-free suites. Considering that $\mathrm{D}^{\mathrm{Ti}_{2}}$ (aug/liq) is dependent on $\mathrm{Fe} / \mathrm{Mg}$ of the melt (Sack and Carmichael, 1984), these estimated differences in $\mathrm{TiO}_{2}$ contents are probably not significant. In addition, the variation in plagioclase composition suggests increasing sodium and potassium during groundmass crystallization. These evolution trends clearly reflect typical low pressure evolution during groundmass crystallization with increasing $\mathrm{TiO}_{2}, \mathrm{FeO}, \mathrm{Na}_{2} \mathrm{O}$, and $\mathrm{K}_{2} \mathrm{O}$.

The strong correlation between $\mathrm{Ti}$ and $\mathrm{Al}^{\mathrm{iv}}$ for many of augite series suggests that the dominating control on partitioning of these elements is related to the $\mathrm{CaTiAl}_{2} \mathrm{O}_{6}$ pyroxene component. The small differences in $\mathrm{Ti} / \mathrm{Al}^{\mathrm{iv}}$ ratios between upper and lower suites at Site 794 may be related to differences in parental magma. Similarly, Na content of augite appear to vary in a systematic way that may reflect differences in parental magmas. These possibilities can be evaluated based on a comparison with whole rock compositions. Only from Site 794 and Site 797 are relatively fresh rock available (Ingle, Suyehiro, von Breymann, et al., 1990; Tamaki, Pisciotto, Allan, et al., 1990). The variations of key elements and ratios have been plotted in Figure 10.
The analyses selected have been affected only to moderate degrees by secondary alteration and reflect the original intruded/extruded magmas. The groupings are only in part consistent with the findings from the mineral compositions. The high $\mathrm{TiO}_{2}$ for the lower suites at Site 794 is consistent with the augite compositions. Despite large variations in the $\mathrm{TiO}_{2}$ content for the basalts of Site 797, this is not clearly reflected in the augite compositions. Although the $\mathrm{Na}_{2} \mathrm{O}$ contents show overlap, their ranges suggest higher contents for the upper suite at Site 794 and the lower suite at Site 797. This is the opposite of the predictions from the augite compositions and may reflect a structural control on the partitioning of sodium into the augites, perhaps dependent on the availability of $\mathrm{Fe}^{3+}$.

The partitioning of potassium into plagioclase has for water-saturated conditions been shown to be dependent on $\mathrm{P}_{\mathrm{H}_{2} \mathrm{O}}$ Yoder et al. (1957) showed that maximum amount of orthoclase accommodated in the plagioclase solid solution would fall as a function of pressure (Yoder et al., 1957; Tuttle and Bowen, 1958). The effect of water-undersaturated conditions on plagioclase composition also has been investigated by Johnson and Rutherford (1989). They showed that the orthoclase component of plagioclase for constant pressure decreased as a function of the mole fraction of $\mathrm{H}_{2} \mathrm{O}$ in the melt. For the Japan Sea rocks, there is no correlation between evidence for high water activity and orthoclase content of plagioclase. Therefore, it is suggested that the observed groupings reflect parental magmas. The high $\mathrm{K}_{2} \mathrm{O}$ content for the upper suite at Site 794 and the lower suite at Site 797 (Fig. 12) is, with one exception (Section 127-794C-12R-4), consistent with the findings from the plagioclase composition.

There exists no reliable information on the whole rock composition for Site 795 for $\mathrm{Na}_{2} \mathrm{O}$ and $\mathrm{K}_{2} \mathrm{O}$; however, the information on $\mathrm{TiO}_{2}$ may be useful. Shipboard analyses (Tamaki, Pisciotto, Allan, et al., 1990) of the basaltic flows at Site 795 have significantly higher $\mathrm{TiO}_{2}$ contents than the upper andesitic flows. This is opposite of the predictions from augite compositions, which have the lowest titanium content for the basalts. This can only can be explained by a strong crystallochemical control on Ti partitioning into the augites.

\section{CONCLUSION}

There are three major groups of magma represented among the rocks drilled during Leg 127 and Leg 128 in the Japan Sea. Site 795 recovered arc tholeiitic magmas characterized by low $\mathrm{Cr}$ and $\mathrm{Ti}$ contents. The second group, which was recovered at Sites 794 and 797 , is olivine basaltic and characterized by plagioclases with relatively low potassium and augites with high titanium (only Site 794) and sodium contents. The third type, recovered at both Sites 794 and 797 , is dominantly olivine-free basalts and contains plagioclases with relatively high potassium and augites with low titanium (only Site 794) and sodium contents. Except for the potassium contents of plagioclase, there is no clear correlation between the compositions of 
Table 4 (continued).

\begin{tabular}{lrrrrr}
\hline \multicolumn{5}{c}{ Titanomagnetite } \\
\cline { 2 - 6 } Hole & $127-797 \mathrm{C}$ & $127-797 \mathrm{C}$ & $127-797 \mathrm{C}$ & $127-797 \mathrm{C}$ & $127-797 \mathrm{C}$ \\
Core/section & $12 \mathrm{R}-2$ & $13 \mathrm{R}-2$ & $21 \mathrm{R}-5$ & $24 \mathrm{R}-6$ & $31 \mathrm{R}-2$ \\
Sample $(\mathrm{cm})$ & $81-83$ & $70-72$ & $101-103$ & $40-41$ & $36-38$ \\
\hline $\mathrm{SiO}_{2}$ & 0.12 & 0.05 & 0.24 & 0.06 & 0.07 \\
$\mathrm{TiO}_{2}$ & 24.21 & 22.97 & 23.48 & 24.94 & 24.12 \\
$\mathrm{Al}_{2} \mathrm{O}_{3}$ & 1.82 & 0.65 & 0.40 & 1.19 & 1.63 \\
$\mathrm{FeO}$ & 51.48 & 50.42 & 45.15 & 51.68 & 50.78 \\
$\mathrm{Fe}_{2} \mathrm{O}_{3}$ & 19.66 & 23.56 & 22.43 & 20.19 & 19.07 \\
$\mathrm{MnO}_{\mathrm{MgO}}$ & 0.82 & 0.92 & 7.58 & 1.61 & 2.25 \\
$\mathrm{CaO}_{\mathrm{Cr}} \mathrm{O}_{3}$ & 0.90 & 0.56 & 0.19 & 0.85 & 0.10 \\
$\mathrm{Total}$ & 0.05 & 0.12 & 0.02 & 0.10 & 0.05 \\
& 0.04 & 0.02 & 0.04 & 0.07 & 0.05 \\
& 99.10 & 99.27 & 99.53 & 100.69 & 98.12 \\
\hline
\end{tabular}

${ }^{\mathrm{a}} \mathrm{FeO}$ and $\mathrm{Fe}_{2} \mathrm{O}_{3}$ are calculated according to spinel stoichiometry.

mineral phases and the rock compositions. The different suites recovered at Sites 794 and 797 appear to represent two distinct and unrelated magma types, mainly characterized by their potassium contents. This conclusion is supported by trace element studies (Allan and Gorton, this volume).

\section{ACKNOWLEDGMENTS}

Discussions with S. Yamashita, K. Stewart, J. Allan, and A. Pouclet during and after the cruise in the Japan Sea greatly clarified many points. The Scientific Shipboard Party of Leg 128 collected the samples used from Hole 794D. S. R. Yang helped with the microprobe at the Johnson Space Center, Houston. Critical comments on the manuscript by R. O. Sack and J. K. Russell were very helpful. The Danish Natural Science Research Council supported the author during ODP Leg 127. The shore-based study was initiated during a National Research CouncilNASA Research Associateship at NASA's Johnson Space Center.

\section{REFERENCES}

Arculus, R. J., and Wills, K.J.A., 1980. The petrology of plutonic blocks and inclusions from Lesser Antilles island arc. J. Petrol., 21:743-799.

Basaltic Volcanism Study Project, 1981. Basaltic Volcanism on the Terrestrial Planets: New York (Pergamon Press).

Beard, J. S., 1986. Characteristic mineralogy of arc-related cumulate gabbros: implications for the tectonic setting of gabbroic plutons and for andesite genesis. Geology, 14:848-851.

Coish, R. A., and Taylor, L. A., 1979. The effects of cooling rate on texture and pyroxene chemistry in DSDP Leg 34 basalts: a microprobe study. Earth Planet. Sci. Lett., 65:75-89.

Gill, J. B., 1981. Orogenic Andesites and Plate Tectonics: Berlin (SpringerVerlag).

Glazner, A. F., 1984. Activities of olivine and plagioclase components in silicate melts and their application to geothermometry. Contrib. Mineral. Petrol., 88:260-268.

Grove, T. L., and Bence, A. E., 1979. Crystallization kinetics of multiply saturated basalt magma: an experimental study of Luna 24 ferrobasalts. Proc. Lunar Sci. Conf., 10:439-478.

Grove, T. L., and Bryan, W. B., 1983. Fractionation of pyroxene-phyric MORB at low pressure: an experimental study. Contrib. Mineral. Petrol., 84:293-309.

Ingle, J.C., Jr., Suyehiro, K., von Breymann, M.T., et al., 1990. Proc. ODP Init. Repts., 128: College Station, TX (Ocean Drilling Program).

Johnson, M. C., and Rutherford, M. J., 1989. Experimental determined conditions in the Fish Canyon tuff, Colorado, magma chamber. J. Petrol., 30:711-737.

Loucks, R. R., 1990. Discrimination of ophiolitic from nonophiolitic ultramafic-mafic allochthons in orogenic belts by the $\mathrm{Al} / \mathrm{Ti}$ ratio in clinopyroxene. Geology, 18:346-349.
Marsh, B. D., Fournelle, J., Myers, J. D., and I-M. Chou, 1990. On plagioclase thermometry in island arc rocks: experiments and theory. In Spencer, R. J., and Chou, I.-M. (Eds.), Fluid-Mineral Interactions: a Tribute to H. P. Eugster. Geochem. Soc., Spec. Publ., 2:65-83.

Nielsen, R. L., 1988. A model for the simulation of combined major and trace element liquid lines of descent. Geochim. Cosmochim. Acta, 52:27-38.

Nisbet, E. G., and Pearce, J. A., 1977. Clinopyroxene composition in mafic lavas from different tectonic settings. Contrib. Mineral. Petrol., 63:149-160.

Papike, J. J., Cameron, K. L., and Baldwin, K., 1974. Amphiboles and pyroxenes: characterization of other than quadrilateral components and estimates of ferric iron from microprobe data. Geol. Soc. Am. Abstr. Programs, 6:1053-1054.

Perfit, M. R., and Fornari, D. J., 1983. Geochemical studies of abyssal lavas recovered by DSRV Alvin from eastern Galapagos rift, Inca transform, and Ecuador rift. 2. Phase chemistry and crystallization history. J. Geophys. Res., 88:10530-10550.

Sack, R. O., and Carmichael, I.S.E., 1984. $\mathrm{Fe}^{2+} \mathrm{z} \mathrm{Mg}^{2+}$ and $\mathrm{TiAl}_{2} \mathrm{z} \mathrm{MgSi}_{2}$ exchange reactions between clinopyroxene and silicate melts. Contrib. Mineral. Petrol., 85:103-115.

Tamaki, K., 1988. Geological structure of the Japan Sea and its tectonic implications. Chishitsu Chosasho Geppo, 39:269-365.

Tamaki, K., Pisciotto, K., Allan, J., et al., 1990. Proc. ODP, Init. Repts., 127: College Station, TX (Ocean Drilling Program).

Tuttle, O.F., and Bowen, N. L., 1958. Origin of granite in the light of experimental studies in the system $\mathrm{NaAlSi}_{3} \mathrm{O}_{8}-\mathrm{KAISi}_{3} \mathrm{O}_{8}-\mathrm{SiO}_{2}-\mathrm{H}_{2} \mathrm{O}$. Mem.-Geol. Soc. Am., 74.

Yoder, H. S., Stewart, D. B., and Smith, J. R., 1957. Ternary feldspars. Yearbook-Carnegie Inst. Washington, 56:206-214.

Date of initial receipt: 21 March 1991

Date of acceptance: 15 November 1991

Ms 127/128B-202

\section{APPENDIX}

Samples Analyzed from ODP Legs 127 and 128

\begin{tabular}{|c|c|c|c|}
\hline Sample & Suite & Unit & Petrographic description ${ }^{a}$ \\
\hline $127-794 \mathrm{C}-2 \mathrm{R}-1,77-79$ & upper & Unit 2 & Plagioclase phyric dolerite \\
\hline $127-794 C-3 R-1,123-125$ & upper & Unit 2 & Plagioclase phyric dolerite \\
\hline $127-794 \mathrm{C}-4 \mathrm{R}-1,44-46$ & upper & Unit 2 & Plagioclase phyric dolerite \\
\hline $127-794 \mathrm{C}-7 \mathrm{R}-1,72-73$ & upper & Unit 3 & Aphyric dolerite \\
\hline $127-794 \mathrm{C}-8 \mathrm{R}-1,4-5$ & upper & Unit 3 & Aphyric dolerite \\
\hline $127-794 C-12 R-2,133-135$ & upper & Unit 5 & Aphyric dolerite \\
\hline $127-794 C-12 R-3,71-73$ & upper & Unit 5 & Aphyric dolerite \\
\hline $127-794 C-12 R-4,85-87$ & upper & Unit 5 & Aphyric dolerite $^{\mathrm{b}}$ \\
\hline $127-794 C-13 R-2,63-64$ & lower & Unit 6 & Aphyric olivine basalt ${ }^{\mathrm{c}}$ \\
\hline 128-794D-13R-1, 87-91 & lower & Unit 7 & Aphyric olivine basalt \\
\hline $128-794 \mathrm{D}-17 \mathrm{R}-1,85-86$ & lower & Unit 8 & Aphyric olivine basalt \\
\hline $128-794 \mathrm{D}-20 \mathrm{R}-1,23-24$ & lower & Unit 8 & Aphyric olivine basalt \\
\hline $127-795 \mathrm{~B}-34 \mathrm{R}-1,46-47$ & upper & Unit 1 & Plagioclase augite phyric andesite \\
\hline 127-795B-36R-2, 49-51 & lower & Unit 3 & Augite plagioclase phyric basalt \\
\hline 127-795B-4IR-1, 107-109 & lower & Unit 3 & Augite plagioclase phyric basalt \\
\hline $127-797 \mathrm{C}-10 \mathrm{R}-1,92-93$ & upper & Unit 2 & Plagioclase olivine? phyric basalt \\
\hline $127-797 \mathrm{C}-11 \mathrm{R}-1,72-74$ & upper & Unit 3 & Plagioclase olivine? phyric basalt \\
\hline $127-797 \mathrm{C}-12 \mathrm{R}-2,74-79$ & upper & Unit 3 & Aphyric olivine basalt \\
\hline $127-797 \mathrm{C}-12 \mathrm{R}-2,81-83$ & upper & Unit 3 & Aphyric olivine basalt \\
\hline $127-797 \mathrm{C}-12 \mathrm{R}-4,35-37$ & upper & Unit 3 & Aphyric olivine basalt \\
\hline $127-797 \mathrm{C}-13 \mathrm{R}-2,70-72$ & upper & Unit 3 & Aphyric olivine basalt \\
\hline $127-797 \mathrm{C}-19 \mathrm{R}-2,42-44$ & upper & Unit 7 & Plagioclase phyric olivine dolerite \\
\hline $127-797 C-21 R-5,101-103$ & upper & Unit 8 & Plagioclase olivine phyric dolerite \\
\hline $127-797 \mathrm{C}-24 \mathrm{R}-6,40-41$ & upper & Unit 9 & Plagioclase olivine phyric dolerite \\
\hline $127-797 \mathrm{C}-29 \mathrm{R}-1,93-94$ & lower & Unit 12 & Plagioclase phyric basalt \\
\hline $127-797 \mathrm{C}-31 \mathrm{R}-2,36-38$ & lower & Unit 13 & Aphyric basalt \\
\hline $127-797 \mathrm{C}-34 \mathrm{R}-1,31-33$ & lower? & Unit 15 & Aphyric basalt \\
\hline $127-797 \mathrm{C}-45 \mathrm{R}-1,49-50$ & lower & Unit 21 & Aphyric dolerite \\
\hline
\end{tabular}

${ }^{2}$ Based on the Initial Reports from Legs 127 and 128 with minor modifications.

${ }^{b}$ Olivine pseudomorphs have been reported from the lower parts of Unit 5 , but this phase was not observed in any of the samples examined.

'Upper chilled margin of Unit 6. Contains microphenocrysts of plagioclase, spinel, and pseudomorphed olivine in a hydrated glassy matrix. 

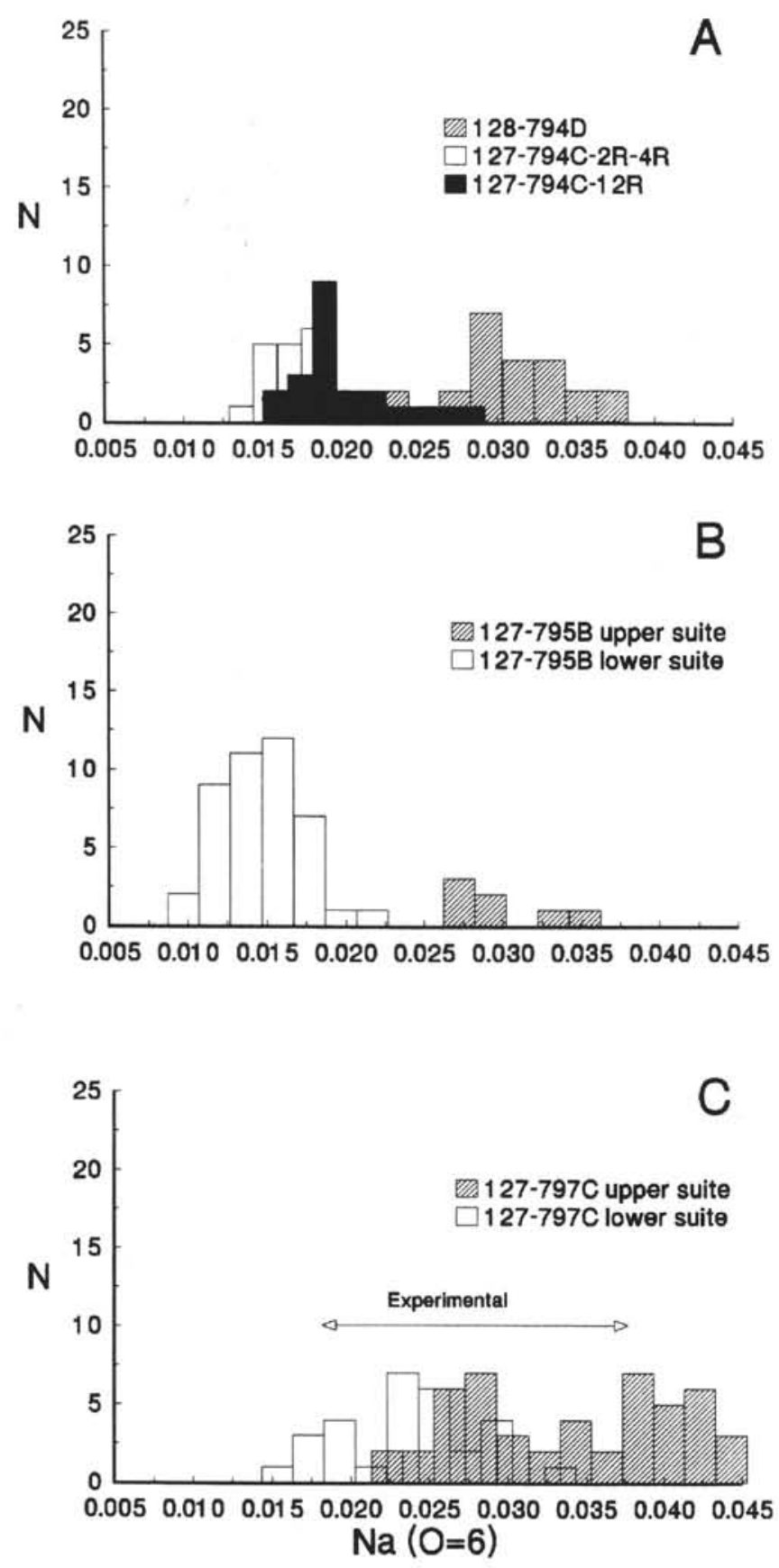

Figure 8. Histograms of Na content $(\mathrm{O}=6)$ of augite. A. Hole $127-794 \mathrm{C}$ and Hole 128-794D. B. Hole 127-795B. C. Hole 127-797C. The experimental results are from Thy (this volume).
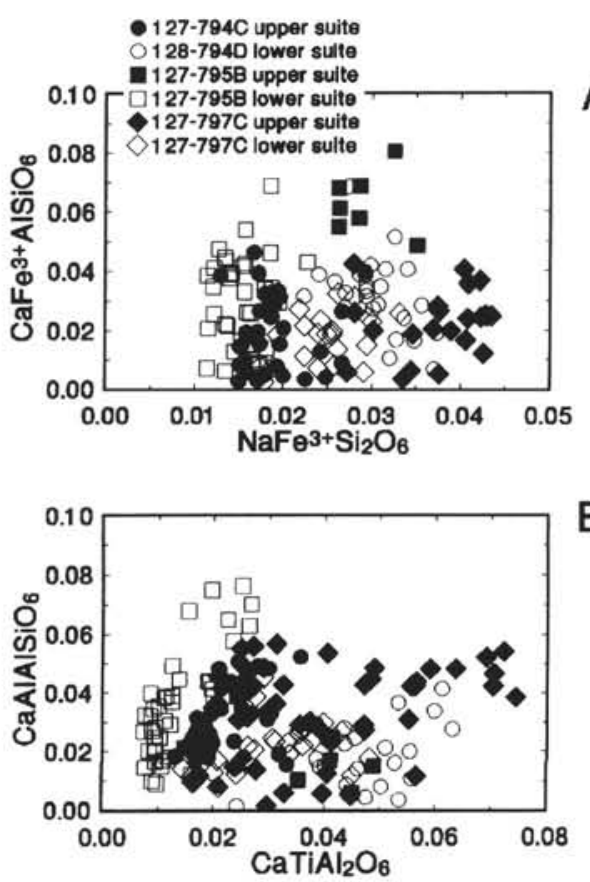

Figure 9. The dominant non-quadrilateral pyroxene end-member molecules calculated as described in the text. A. $\mathrm{CaFe}^{\mathrm{iv}} \mathrm{AlSiO}_{6}$ vs. $\mathrm{NaFe}^{3+} \mathrm{Si}_{2} \mathrm{O}_{6}$. B. $\mathrm{CaAlAISiO}_{6}$ vs. $\mathrm{CaTiAl}_{2} \mathrm{O}_{6}$.
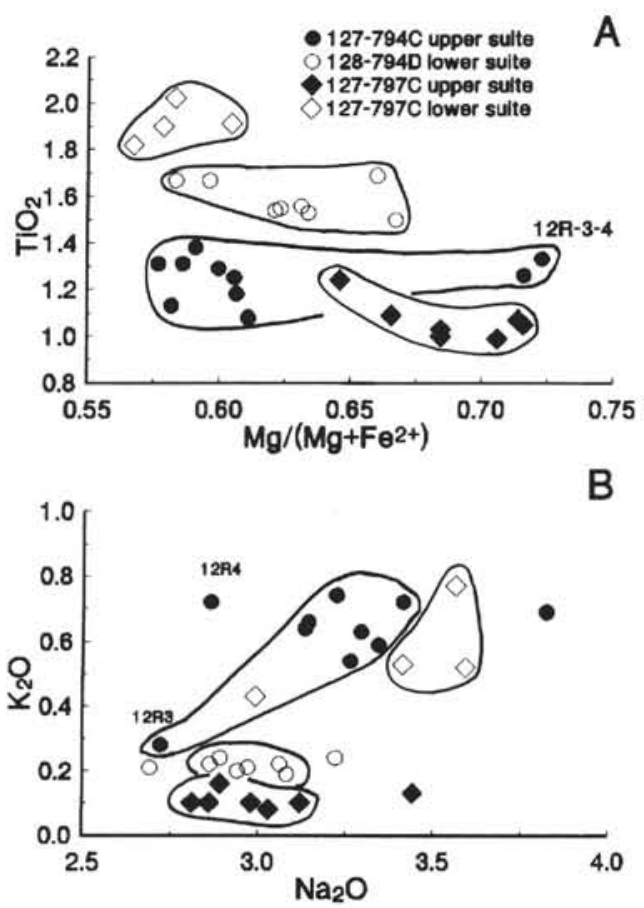

Figure 10. Whole rock composition of rocks from Sites 794 and 797. Only the most fresh rock has been selected and all have been calculated anhydrous to $100 \%$ with all $\mathrm{Fe}$ as $\mathrm{Fe}^{2+}$. A. $\mathrm{TiO}_{2}$ vs. $\mathrm{Mg} /\left(\mathrm{Mg}+\mathrm{Fe}^{2+}\right)$. B. $\mathrm{K}_{2} \mathrm{O}$ vs. $\mathrm{Na}_{2} \mathrm{O}$. 


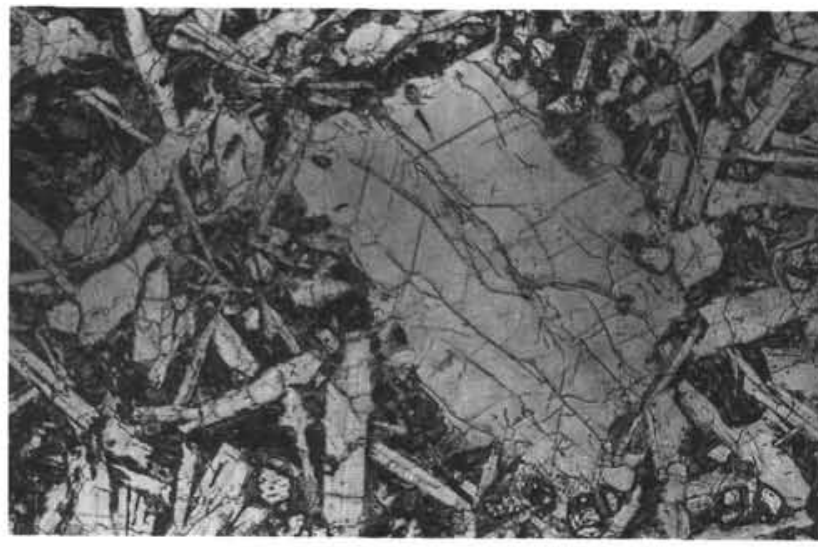

1

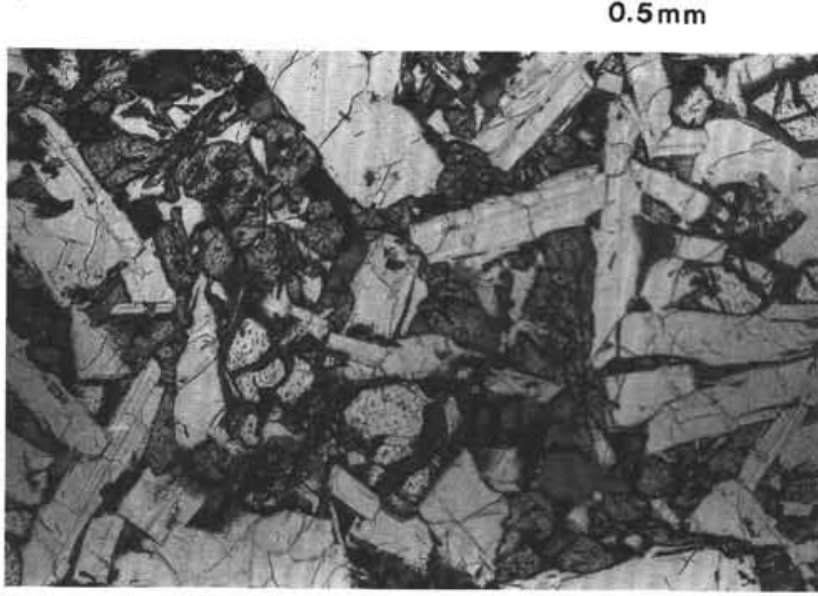

3

$0.5 \mathrm{~mm}$

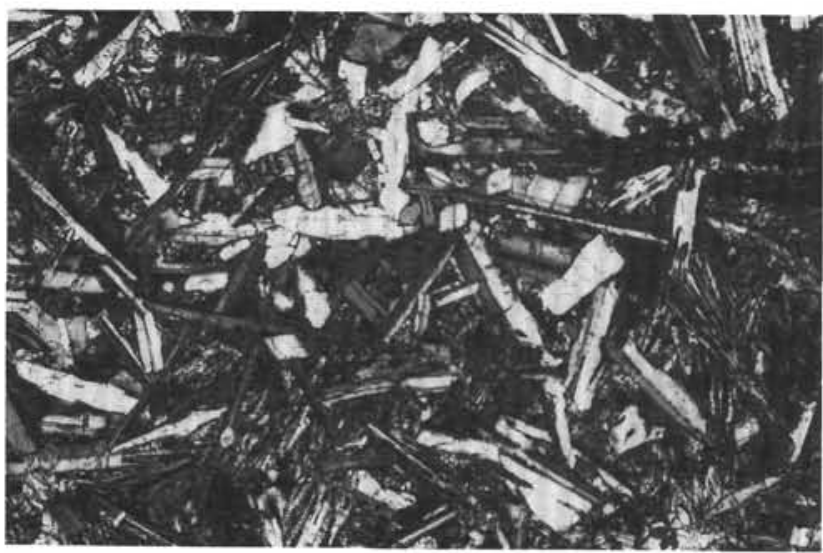

5

$0.5 \mathrm{~mm}$

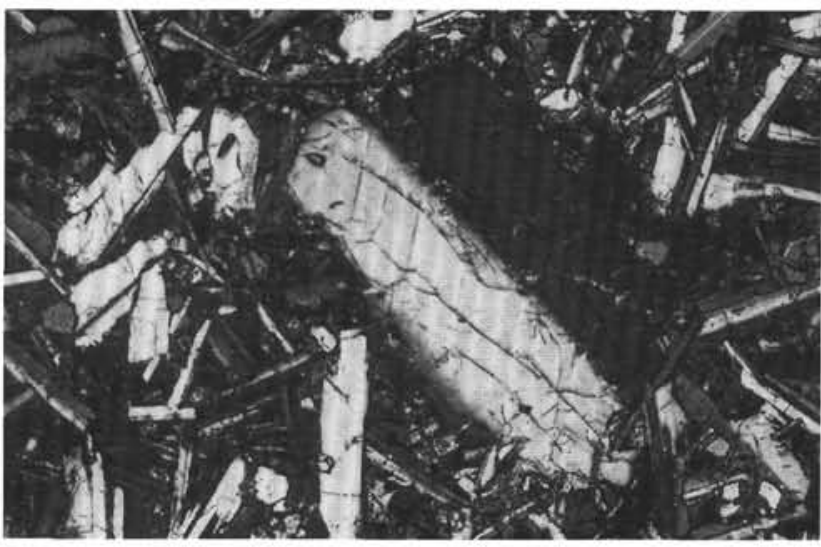

2

$0.5 \mathrm{~mm}$

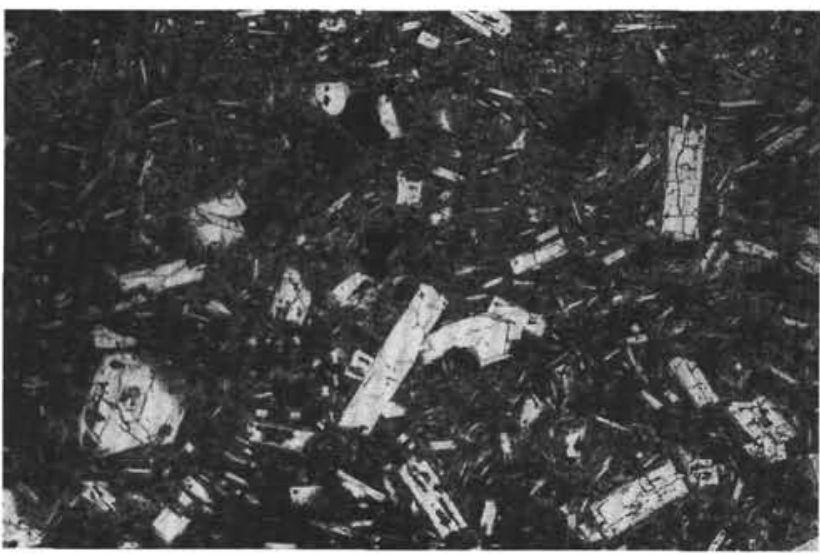

4

$0.5 \mathrm{~mm}$

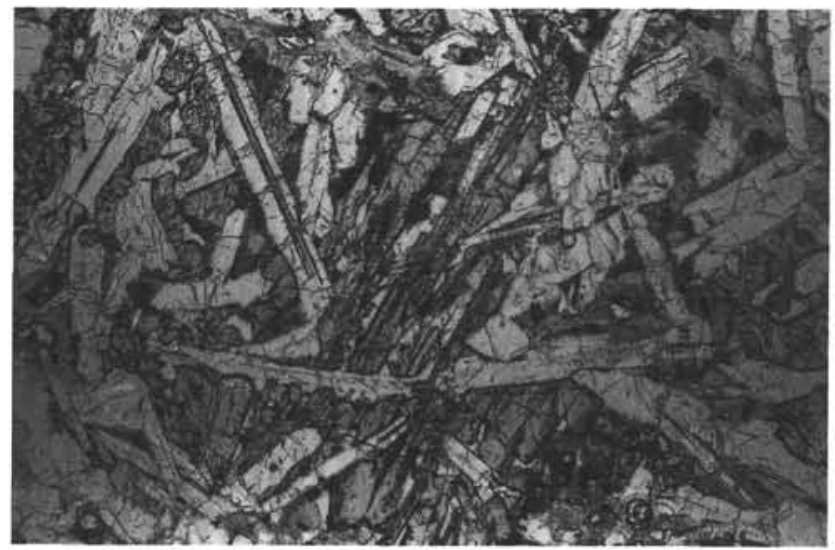

6

\section{$0.5 \mathrm{~mm}$}

Plate 1. Microphotographs of relatively unaltered rocks from Sites 794, 795, and 797. 1. Sample 128-794D-20R-1, 23-24 cm. Plagioclase and olivine microphyric groundmass with plagioclase phenocryst. 2. Same sample, crossed nicols. 3. Sample 128-794D-13R-1, 87-91 cm. Aphyric basalt with an intergranular groundmass of plagioclase, augite, and olivine. 4. Sample 127-795B-34R-1, 46-47 cm. Plagioclase, augite, and magnetite phyric andesite with partly altered groundmass. 5. Sample 127-797C-12R-2, 133-135 cm. Aphyric basalt with a groundmass composed of plagioclase, augite, and olivine (crossed nicols). 6. Same sample, without crossed nicols. Magnification of the groundmass with skeletal augite and late crystallizing magnetite. Scale bar is 0.5 mm for all photographs. 